\title{
Infectious diseases
}

\section{Annual review of significant publications}

\author{
Hobart A. ReIMANN \\ M.D. \\ The Hahnemann Medical College and Hospital, Philadelphia, U.S.A.*
}

\section{Introduction}

Publications in 1966 indicated the continued search for new and better antimicrobic drugs, but also emphasized many harmful effects from their logical application and especially from their indiscriminate use. Alarm again was raised about the increasing incidence of nosocomial and iatrogenic infections caused by antimicrobic-resistant Gramnegative bacilli, by latent viruses and fungi. More facts accrued about the multitropism of viruses usually regarded as selective of one tissue or organ. Progress was made in the preparation of vaccines against a number of viral diseases and antiviral chemical agents for their prevention and treatment are under investigation. The aetiologic relation of viruses to cancer and lymphomas in man remains unclear. The Asian epidemic of cholera provided opportunity for extensive investigation. War in south-eastern Asia induced a resurgence of interest in exotic infections.

\section{Antimicrobic agents}

The indiscriminate application of antimicrobics continues. An investigation in eighteen hospitals disclosed that $26 \%$ of patients received antibiotics, in one instance $40 \%$. Patients in a 500-bed hospital paid $\$ 20,000(£ 6944)$ in 1 month for antimicrobics which accounted for $60 \%$ of the total charge for drugs. Twelve pounds $(5.5 \mathrm{~kg})$ of penicillin were dispensed monthly! Because so few infections are amenable to antimicrobic therapy, an estimated $90 \%$ of it is unnecessary. ${ }^{1}$ Eight tons of penicillins were prepared in 1964, and 2000 semisynthetic ones have been investigated.

It is of interest that 75 years ago quinine was regarded as the 'wonder' drug and was used as indiscriminately for respiratory tract infections and for fevers in general as antimicrobics are used now. Menthol in an oily nasal spray, antipyrin,

*Dr Reimann is Field Director pro tem of the American Medical Association Project in Medical Education at the Saigon Medical School, Vietnam. Reprints of this paper are not available. acetanilid and phenacetin, now known to be dangerous, were and still are widely used for treatment. ${ }^{2}$ Because bodily temperature higher than the norm is unfavourable to viruses, antipyretic drugs rarely should be prescribed for fever.

Reports of the failure of antimicrobic prophylaxis for surgical wound infections continue to appear, ${ }^{3}$ but seem to be generally unheeded. No differences accrued in the number of postoperative infections among 150 surgical patients whether or not patients received methicillin or chloramphenicol.4 The same applies to prophylaxis for extensive burns. ${ }^{5}$

In a 5-year study, British observers found little benefit either prophylactically or therapeutically from the administration of antimicrobics to vic? tims of chronic bronchitis. ${ }^{6}$ This is not surprising if viruses often are causes. In one study of fifteen patients for 2 years, seventy-five periods of illness were associated with viruses, $23 \%$ of which were rhinoviruses.7 'Anticold' nostrums that contain antimicrobics were suppressed by the U.S. Federal Drug Administration.8

A useful outline of measures used to select appropriate antimicrobics, the manner of their application and precautions against adverse reactions was published. ${ }^{9}$ If it is adopted much needless therapy would be avoided.

\section{New antimicrobics}

Among newly introduced antimicrobics are ferrimycin, verrucarin, moenomycin, kasugamycin, sugordomycin, ${ }^{10}$ hetacillin, doxycycline, hedamycin, leucomycin, rifamycin, rondomycin, garamycin, hamycin and lysostaphin.11 One wonders how many are different and superior to ones now in use, and which ones will survive the test of time. Several authorities doubt that those now at hand will be superseded. The bewildering number of antimicrobics makes it difficult for a physician to decide which one to use for what infection, how much to use and how.

Ampicillin is bactericidal and resembles cephalothin and tetracycline in its effects. It is active 
against enterococci and Proteus, but not against penicillin-resistant staphylococci, Klebsiella or Pseudomonas. ${ }^{12}$ It was as effective as penicillin for the treatment of bacterial pneumonias, ${ }^{13}$ for pneumococcal, meningococcal and $\mathrm{H}$. influenzal meningitis. ${ }^{14}$ Cloxacillin, another semisynthetic penicillin, acts like oxacillin and against penicillinresistant staphylococci. ${ }^{15}$

For several reasons, including its greater action against gonococci, ${ }^{16}$ cephaloridin is superior to cephalothin. ${ }^{17}$ It was effective against all Grampositive coccal infections, excepting enterococci, against penicillin-resistant staphylococci, most strains of coliforms and some strains of Proteus. Large dosage was nephrotoxic. ${ }^{18,} 19$ Cephalothin may cause allergic reactions in patients sensitive to penicillins. ${ }^{20,21}$ Cephalosporin cured endocarditis in penicillin-sensitive patients. ${ }^{22}$

Kanamycin attacks Gram-negative bacilli excepting Pseudomonas, and is useful for tuberculosis that resists other agents. Some staphylococci have become resistant. Thirty tons of kanamycin were used in 8 years, but it is being supplanted by semisynthetic penicillins. ${ }^{23}$ Gentamycin is bactericidal and more active than streptomycin and kanamycin against Pseudomonas and also is active against neomycin-, bacitracinand kanamycin-resistant staphylococci. ${ }^{24}$

Penicillin, erythromycin, ampicillin and lincomycin were equally effective in the treatment of haemolytic streptococcal infections in children and in eliminating cocci from the throat. Ten to 30 days after therapy, recurrent infection or the carrier state ensued in about $20 \%$ of patients. ${ }^{25}$ Drugs of choice for $E$. coli infections are ampicillin and tetracycline; for nonmotile Klebsiella, cephalothin and kanamycin; for motile Aerobacter, kanamycin and chloramphenicol; for Proteus mirabilis, ampicillin and kanamycin; for indole-positive Proteus, kanamycin; and for Pseudomonas, colistin and polymyxin B. ${ }^{26}$ According to Foster's advice, kanamycin or neomycin is best for $E$. coli infections ; tetracycline or chloramphenicol for Aerobacter and neomycin or kanamycin for resistant Proteus. ${ }^{27}$ Evidently, at present, opinions differ.

Candicin, whose antifungal spectrum resembles amphotericin B, was effective in the treatment of candidal vaginitis and tolfanate for the treatment of cutaneous infections. ${ }^{28}$

At the December conference arranged by the New York Academy of Sciences, ampicillin was said to increase more slowly, attain a lower level, and persist longer in the blood than penicillin because of lesser renal excretion. Ampicillin changes to hetacillin in vivo and neither are effective against coliforms, aerobic streptococci or
Bacteroides. Ampicillin is as effective as chloramphenicol for typhoid and is of value in treating enterococcal endocarditis, meningococcal meningitis and shigellosis. Hetacillin cured pneumococcal pneumonia, but was ineffective for Klebsiella, Pseudomonas and penicillinase-producing staphylococci. Ampicillin, cephalothin and cephaloridine were of equal value for urinary tract infections. Kanamycin, though toxic, probably is the best single drug for Gram-negative bacillary infections. Lincomycin was not mentioned. Corticosteroid therapy is of doubtful value for the treatment of shock in Gram-negative bacillary sepsis.

\section{Unwanted effects of antimicrobics}

Reactions to drugs occurred in about $11 \%$ of patients in a hospital. ${ }^{29}$ Elsewhere, $20 \%$ of patients had iatrogenic disease either from therapy or diagnostic procedures. Pseudomonas infections followed the use of cephalothin and Klebsiella infections occurred after therapy with ampicillin. In a 10-year period, 109 instances of staphylococcal enteritis occurred among patients who received antimicrobics prophylactically, chiefly chloramphenicol, during abdominal surgery. Vancomycin given orally was recommended for its treatment. ${ }^{30}$ Despite the use of antimicrobics or because they were used, the incidence of bacterial infections of the newborn increased in a hospital. The predominant causes were Gram-negative bacilli. ${ }^{31}$ Gram-negative bacillary septicemia increased seven-fold in a decade in Cincinnati hospitals, mostly in children and in persons more than 60 years old. The death-rate was $67 \%$. Elsewhere the incidence of Gram-negative bacillary pneumonias, as found post-mortem, rose from $0.8 \%$ in 1952 to $7.9 \%$ in 1963 . The increase was attributed to antimicrobic therapy and contaminated apparatuses for inhalation therapy, especially in debilitated patients. ${ }^{32}$ Candidiasis also has increased in incidence from the use of antimicrobics. 33

About $8 \%$ of patients treated with penicillin reacted adversely to it and from 100 to 300 deaths from anaphylaxis occur yearly in the United States. ${ }^{21,} 29$ Antibody to penicillin appeared in the blood in $1-8 \%$ of patients treated with the drug. Huge doses caused haemolytic anaemia in several instances $^{34}$ and severe neural disturbances in others. 35 Accidental arterial entry of penicillin injected into buttocks caused transverse myelitis, occlusion of arteries of a leg and gangrene in infants. ${ }^{36}$ Penicilloyl-polylysine used as a dermal test caused a severe reaction in one patient ${ }^{37}$ and gave positive results in $22 \%$ of others. 21

Prolonged administration of chloramphenicol caused visual impairment in victims of cystic 
fibrosis as described in three papers in the January 1966 issue of the Journal of Pediatrics, and optic neuritis in others. ${ }^{38}$ Kanamycin is ototoxic and nephrotoxic. ${ }^{23}$ Prolonged oral administration of neomycin in volunteers caused malabsorption and steatorrhea. ${ }^{39}$ Applied locally, it increased the incidence of allergic dermatitis. ${ }^{40}$ Isoniazid and paraaminosalicylic acid may cause sideroblastic anaemia by interfering with the metabolism of pyridoxine.

Genetic transfer of drug-resistance among Gram-negative enteric bacilli was first observed in Japan ${ }^{41}$ and later in England ${ }^{42}$ and in the United states. 43, 44 Various antimicrobic-resistant strains of enterobacteria have their resistant genes on an episome and transfer this factor to sensitive bacilli by conjugation in mixed culture. Surprisingly, antimicrobic-resistant Salmonella transferred resistance factors to recipient strains of $E$. coli. ${ }^{45}$ Transduction of antimicrobic resistance also occurs among staphylococci.46 Extensive clinical and agricultural use of antimicrobics and the resultant widespread increase of the transferable $\mathbf{R}$ factors threaten the emergence of serious therapeutic problems. ${ }^{44}$

\section{Nosocomical infections}

Bacteria and other microbes once regarded as harmless are important causes of 'hospital' infections. They are invasive because of impaired resistance of patients resulting from corticosteroid therapy, overuse of antimicrobics, instrumentation and for other reasons. Staphylococcus, Salmonella and Gram-negative bacilli chiefly are implicated. Acute staphylococcic arthritis occurred in elderly victims of rheumatoid arthritis, four of whom had received prolonged steroid therapy.47 Pseudomonas infected patients after intraocular 48 and urologic operations 49 and others from contaminated respiratory apparatus ${ }^{50}$ and catheters. ${ }^{51}$ Aerobacter (now called Enterobacter) caused nine infections in a 5-month period in patients with chronic diseases. Excepting streptomycin, the bacilli resisted antimicrobics, as did $E$. coli and Klebsiella. ${ }^{53}$ Type 25 Klebsiella caused sepsis as a contagious infection in six children during 8 days. ${ }^{54}$ Serratia marcescens (B. prodigiosis, now included in the tribe Klebsiella as genera Serratia ${ }^{52}$ ) from a contaminated plastic bottle caused infections in infants, ${ }^{55}$ and often was isolated from patients treated with antimicrobics and from debilitated ones. It was resistant to most antimicrobics. ${ }^{56,57}$ Thrombocytopenia, said to be a diagnostic sign of Gram-negative bacillary disease, ${ }^{58}$ is unspecific and occurs during many other infections. ${ }^{113}$

Cytomegalic inclusion disease was present in eight of twenty-five patients who had received renal homotransplants and immunosuppressive drugs. ${ }^{59}$ Of 111 other patients fifty-five died. Pneumonia was present in forty-one and was associated with Pneumocystis carinii in ten. In nine of these, other microbes also were present .60 Fatal strongyloidiasis occurred in patients receiving corticosteroids. ${ }^{61}$

The control of hospital-acquired infections was the subject of a symposium published by the U.S. Department of Health, Education and Welfare, Communicable Disease Center, Atlanta, Georgia, 4-5 September 1963, pp. 1-203.

\section{Viral respiratory tract infections}

Respiratory tract infections comprise $58 \%$ of acute diseases in the United States. ${ }^{62}$ Viruses caused $50 \%$ of respiratory tract infections of 286 students. Of these, rhinoviruses caused $17 \%$; para-influenza, $13 \%$; influenza, $11 \%$; respiratory syncytial, $4 \%$ and coxsackie viruses, $3 \% .63$ Herpes simplex virus caused respiratory tract infections with pneumonia in six patients. ${ }^{64}$ Ryan virus, newly isolated from patients with respiratory tract and systemic infection, may be related to herpes viruses. 65

A normal or subnormal number of circulating leucocytes is generally regarded as characteristio of viral infection. However, among infants wit respiratory tract infections caused chiefly by $R S$ para-influenza and adenoviruses, the median leucocyte count was $14,000 / \mathrm{mm}^{3}$ and in asymptomatic patients, 9000.66

\section{Rhinovirus}

Specific antibody appeared in the blood of victims of rhinovirus infection after 14-17 days, and in nasal, salivary and lacrimal secretions after 24 days. ${ }^{67} \mathrm{~A}$ rhinovirus and a para-influenza virus were recovered from a patient with a cold. Both viruses caused illness when inoculated into volunteers. The rhinovirus induced immunity ; the parainfluenza virus did not. 68 Enteric coated capsules of two types of live rhinovirus ingested by volunteers failed to cause illness and no antibody appeared. ${ }^{69}$ The virologic, epidemiologic and preventive problems of rhinoviruses and the common cold were summarized by Andrewes. ${ }^{70}$

\section{Influenza}

An injection of influenza vaccine caused an adverse reaction in $25 \%$ of vaccinated employees of a large company and the antibody response was poor. A second injection evoked a response in $80 \%$ to $\mathrm{B}$ virus and in $27 \%$ to $\mathrm{A}$ virus. ${ }^{71}$ Amantadine hydrochloride was said to be effective for the prevention of influenza. One per cent of treated persons as compared with $4 \%$ of control subjects 
became sick. ${ }^{72}$ Although its value has not been established, a related drug, Symmetrel, will be available commercially soon for the prevention of influenza. According to one report amantadine given prophylactically suppressed febrile influenza $\mathbf{A}_{2}$ infection in children. ${ }^{73}$ Large dosage is apt to cause mental disturbance. Hopefully, it will be more effective than is thiosemicarbazone for smallpox. The presence of neutralizing antibody in the blood failed to prevent infection of volunteers with minimal amounts of inhaled virus. ${ }^{74}$ Antibody against para-influenza virus is greater in strength in nasal secretion than in the blood. ${ }^{75}$

Rapid diagnosis of influenza can be made by the use of fluorescent-antibody technique, but the results of the test are irregular and often nonspecific. ${ }^{76}$ Another 'new' virus unrelated to myxoviruses was isolated from victims of mild respiratory tract infection. ${ }^{77}$

\section{Adenoviruses}

Inoculation of volunteers by inhalation of aerosolized adenovirus Type 4 caused illness resembling the naturally occurring disease and two had viral pneumonia. The rest were inapparently infected. ${ }^{78}$ Orally administered adenoviral Type 4 vaccine in enteric-coated capsules caused inapparent intestinal infection and protected recruits against infection with that virus. ${ }^{79}$ The injection of non-infectious specific antigens of adenovirus Types 1 and 2 induced antibody that persisted 4-12 months. ${ }^{80}$ Methisazone inhibits the multiplication of adenoviruses similar to that of pox viruses. ${ }^{81}$ Experimentally, adenovirus type 7 was transformed into type 2.82

\section{Respiratory syncytial $(R S)$ virus}

RS virus caused moderately severe illness in 106 Russian children, eighty-five of whom had viral pneumonia, ${ }^{83}$ confirming previous observations of the seriousness of that infection in infants and children. Ampicillin had no therapeutic effect on bronchiolitis probably caused by $\mathrm{RS}$ virus. ${ }^{84}$ Vaccines against $R S$ and para-influenza viral infections are under study. ${ }^{85}$

Vaccination with para-influenza vaccines types 1,2 and 3 evoked antibodies in most infants. ${ }^{85}$ The incidence of acute respiratory tract infections in children was reduced $15 \%$ by immunization with a heptavalent vaccine (RS, para-influenza 1, 2 and 3, influenza $A_{2}$ and $B$ viruses and Mycoplasma pneumoniae organisms). The absence of influenza $A_{2}$ and $B$ in the community suggested that vaccination prevented infection with parainfluenza and mycoplasma microbes. Ten weeks after injection, vaccination no longer was effective. ${ }^{87}$ Hilleman summarized current knowledge about vaccines, chemotherapy and host resistance in viral infections. ${ }^{88}$

Reo virus was considered as an uncommon cause of infection, but specific antibody was demonstrated in $55 \%$ of children. 89

\section{Mycoplasmal respiratory tract infection}

As predicted from epidemiologic and clinical observations 25 years ago there are two general forms of acute respiratory tract infections, one with a short incubation period with a predominance of mild disease; the other, a nonseasonal one, with a 2-3 week incubation period and a high proportion of severe disease and pneumonia, no doubt, was caused by Mycoplasma pneumoniae. ${ }^{90}$ Recently, that agent caused disease in twenty-three observed families. Eighty-four per cent of the children and $41 \%$ of adults were infected. Of fifty-nine patients, nine were not sick, six had pharyngitis and forty-two had pneumonia that often was unrecognized without skiagraphy. Tetracycline seemed neither to relieve the symptoms completely nor to end the carrier state. ${ }^{91}$ Elsewhere, the infection occurred throughout the year, but especially in the summer and seldom was severe in children. ${ }^{92}$

In another study, $M$. pharyngis and $M$. salivarium present in $50 \%$ of pneumonic patients were not causal. $M$. pneumoniae was recovered in $9-20 \%$ of patients and accounted for $13-50 \%$ of non-pneumococcal pneumonias. The cold agglutinin test was not discriminative in diagnosis. ${ }^{93}$ Nor was it of diagnostic value among 444 children with respiratory tract infections. In $28 \%$, the test gave a positive result without other evidence of mycoplasmal infection. ${ }^{94}$

An antigenic formalin-killed vaccine was prepared and recommended for use because of the severity and duration of the infection. .95 Others doubted the need for vaccination because of the preponderance of mild illness. ${ }^{92}$

\section{Other viral infections}

\section{Measles}

Naturally occurring measles evoked the highest antibody titre ; vaccine and immune globulin less, inactivated vaccine and live vaccine the lowest. ${ }^{96}$ Vaccination with live attenuated virus induced specific antibody in most of Eskimo and white children. Fever of $103^{\circ} \mathrm{F}\left(39.4^{\circ} \mathrm{C}\right)$ and a rash ensued about 1 week later in one-third of the Eskimo vaccinees.97 Measles vaccine caused lymphadenopathy which may be mistaken for other disease. ${ }^{98}$ In one infant, inguinal adenopathy persisted for 2 weeks. ${ }^{99}$ Because only $85 \%$ of vaccinated children in Britain were protected against measles, routine immunization of children 
was postponed.100 Diagnosis of measles can be made 2 days before to 5 days after the rash appears by the use of a fluorescent-antibody procedure on the urinary sediment. 101

Mumps, at times, may evoke an exanthem or an enanthem.102 There is evidence for ${ }^{103}$ and against 104 the causal relationship of gestational mumps to endocardial fibroelastosis. Antimumps vaccine was not recommended for exposed persons, 105 but a newly prepared live attenuated virus was said to be highly successful. ${ }^{106}$

\section{Rubella}

In Alaska, rubella was as contagious as measles. Inapparent infections were common in persons who had lived during a previous epidemic and evidence of second attacks was observed.107 Elsewhere, two infants with congenital rubella were born by mothers who had not had rubella nor were exposed to it. The infants' blood contained antibody, the virus was excreted for months and several attendant persons were infected.108 Arthritis frequently occurs in the hands. ${ }^{109}$ Five instances of rubellar encephalitis were observed 110 and virus was present in the brain of several infants.11 Thrombocytopenia and purpura were noted in fifteen victims one of whom died.112 This occurrence is not peculiar to rubella and may occur in most other infections. ${ }^{113}$ Rubella and measles early in pregnancy and hepatitis later were more dangerous to the foetus than varicella.114

Intradermally inoculated virus caused overt or inapparent rubella in seven volunteers. Others with pre-existing antibody were immune. ${ }^{115} \mathrm{~A}$ haemagglutinin-inhibition test determines the presence or absence of specific antibody in $3 \mathrm{hr} .116$

Varicellar lesions in the bladder apparently caused haematuria in two children with chickenpox. ${ }^{117}$ In others, lesions were seen by cystoscopy. ${ }^{118}$ Renal lesions and haematuria were described in a patient with infectious mononucleosis.119 These observations together with mention later of ECHO virus, ${ }^{175}$ are among the first to show viral infection of the urinary tract. The virus of lymphocytic choriomeningitis, by its name, was considered as a neural infection, but in ten laboratory workers the infection without meningeal invasion was contracted from infected hamsters. The symptoms and signs were fever, aching, lymphadenopathy and an enanthem which lasted 3 weeks. ${ }^{120}$ Observations mentioned in this paragraph add to the evidence that viruses are multitropic.

\section{Vaccines}

An attenuated live rubella virus vaccine was immunogenic and the induced infection did not spread to susceptible children. ${ }^{121}$ Live virus vac- cines of any kind should not be inoculated during pregnancy lest the embryo be infected. Influenza and polio vaccines were said not to be teratogenic, 122 but defective infants were born of two mothers who had received polio vaccine during pregnancy. 123 A rare instance of paralytic poliomyelitis occurred in a mother 22 days after her child received vaccine orally.124 Administration of live polio vaccine temporarily suppressed the tuberculin reaction in children. ${ }^{125}$ Fatal vasculitis occurred after vaccination against pertussis. ${ }^{126}$ The first known instance of fatal encephalitis followed inoculation of yellow fever vaccine. Fifteen non-fatal cases are on record. 127

According to one report, sixteen foetuses with generalized vaccinia were delivered from mothers who had received vaccinia vaccine during pregnancy, 128 but in another study of sixty-five women no virus was in the placenta, nor were the infants harmed. ${ }^{129}$ Fourteen children had meningococcal meningitis and two had pneumococcal meningitis 4-21 days after anti-smallpox vaccination, attributed to post-vaccinial impaired resistance. ${ }^{130}$ Vaccinia vaccine causes more complications than any other biologic product according to Thomson who summarized the problem of 'mass' immunization for the control of infectious diseases. ${ }^{131}$

The increasing number of immunizing agents raises questions as to which ones really are effective, how many a person should receive alone or combined, which ones to use, when and how, and if any harm ensues. At present, agents are available against smallpox, poliomyelitis, measles, yellow fever, influenza, adenoviruses and rabies, typhoid, cholera, tuberculosis, pertussis, plague, pneumococcosis, tetanus and diphtheria. Under investigation are vaccines for $\mathrm{RS}$, mumps, parainfluenza, rhinovirus, rubella and Japanese $B$ viruses, mycoplasma, Q fever, streptococcosis, tularaemia, anthrax and others. The status of vaccines incorporated with adjuvants to increase their potency was reviewed by Hilleman. 132

The possibility that adenoviruses may be oncogenic has precluded the use of these live virus vaccines. If they do cause cancer, then properly prepared vaccines should not only prevent adenoviral respiratory tract infections safely, but also prevent the resultant cancers and their metastases after excision of the primary site. 133

\section{Chemotherapy of viral infections}

Thiosemicarbazone for the treatment of smallpox has not fulfilled its early promise. Given prophylactically, it reduced the incidence of infection slightly, but not the fatality rate. It was not recommended for routine use.134 IDU (5-iododeoxyuridine) for prevention will be tested in India. ${ }^{135}$ In a limited trial, methisazone failed 
as a prophylactic agent against varicella.136 Predictably, many reports of tests of the drug in other viral infections will appear. Electron microscopy of virus particles in vesicular fluid or crusts provides a method of diagnosis of variola and varicella within minutes. ${ }^{137}$ Therapy with cortisone and $\mathrm{N}$-ethylisatin B-thiosemicarbazone reduced the inflammatory response in the brain of mice infected with neurovaccinia virus. 138

Despite contradictory evidence, idoxiuridine when used properly was effective in the treatment of cutaneous herpes simplex. Treatment must be applied at short intervals after the first evidence of lesions and for about 4 days. ${ }^{139} \mathrm{~A}$ patient with herpes simplex encephalitis recovered after craniotomy was performed and IUDR was injected intravenously. ${ }^{140}$ Herpes virus and SV40 virus particles, present in the same nuclei of simian renal cells, suggested the possibilities of phenotypic mixing and the production of different viral particles. ${ }^{141}$ Antiviral substances were sought in Chinese plants. One derived from magnolias and narcissi was active against lymphocytic choriomeningitis virus. ${ }^{142} \mathrm{~A}$ review of therapeutic measures for viral diseases was published. ${ }^{143}$

\section{Viral encephalitis}

Herpes simplex virus caused encephalitis 144,145 and pneumonic respiratory tract infection in which oral vesicles also were present. ${ }^{64}$ Meningoencephalitis occurred in twenty-five patients with herpes zoster with one death, 146 and in sixteen children with measles. ${ }^{147}$ The occurrence of asymmetric neural signs resembling the effects of a tumor caused diagnostic difficulty. 148

Adenovirus type 7 probably was the cause of encephalitis in one of three infected siblings. ${ }^{149}$ Several antigenic types of the California encephalitis virus appear to be unstable. They are widely distributed in the world and increasing numbers of infections in man are reported. An epidemic occurred in Indiana in 1965. Children are involved chiefly and inapparent infections are common. Ninety-six cases have been recorded. 150 Man seems to be accidental dead-end host. ${ }^{151}$ During an epidemic of St Louis virus encephalitis in Texas, virus was isolated from bats in the vicinity. ${ }^{152}$

Although rabies in man is considered always to be fatal, it is possible that milder attacks have occurred unrecognized many months after infection. In vaccinated victims, illness caused by the vaccine may resemble rabies, but proof of diagnosis rests on isolation of the virus. Instances of recovery from rabies have been cited, ${ }^{153}$ but are unconvincing. Study of the matter is in progress. ${ }^{154}$ Hyperimmune serum and vaccine are the best available agents for prevention, but ten in- stances of failure are known. ${ }^{155}$ The matter was reviewed.156, 157 A monkey developed rabies in a laboratory. ${ }^{158}$

\section{Viral hepatitis}

Infectious hepatitis has recurred in 7-year epidemic cycles, but the interval seems to be lengthening. ${ }^{159}$ After a high incidence in 1960-61, the present rate of occurrence indicates a downward trend. 160

The occurrence of eight cases of hepatitis in hospital employees in a year indicated a greater risk of infection for them than for the general population. Education in basic aseptic technique is of more value in prevention than the injection of $\gamma$-globulin. 161 Among 3529 oriental military men in Taiwan, tests of their blood disclosed evidence of anicteric hepatitis which progressed to chronicity and cirrhosis. Whether all of these patients had viral hepatitis or other disease is uncertain.162 Acute hepatitis was fatal in two of three women after parturition. ${ }^{163}$ Hepatitis ensued in five of nine patients treated with fibrinogen. ${ }^{164} \gamma$-Globulin failed to prevent post-transfusion hepatitis when injected before cardiac surgery and a month later. The incubation period was less than 50 days in half of the patients. ${ }^{165}$ Adenovirus Type 5 was present in blood clots from twenty-seven of thirty patients with infectious hepatitis and in only one from seventy control persons. ${ }^{166}$ Questions are: does hepatitis favour the growth of the virus or was the virus causal?

A disease resembling icteric infectious hepatitis, but with a negative heterophile reaction, was caused by cytomegalovirus. Infection was transmitted to a person in contact with the patient. ${ }^{167}$

\section{Enteroviruses}

Coxsackie B3 virus was added to the list of causes of hepatitis, myocarditis and pleuritis. ${ }^{168}$ Virus B4 caused neural and valvular endocarditis in inoculated mice. It is probable, at times, that this and other viruses are responsible for endocarditis in man, especially in the absence of streptococcal or rheumatic infection. ${ }^{169}$ Virus A16 was recovered from children with 'hand, foot and mouth' disease, at first mistaken for measles. There were high fever, meningoencephalitis, an enanthem, and extensive dermal desquamation in the places named. ${ }^{170}$ The disease was observed in Wisconsin ${ }^{171}$ and in Denmark. ${ }^{172}$ Curiously, a similar infection of cattle, horses and swine is caused by the Indiana-type vesicular stomatitis virus. Accidental infection in laboratory workers resulted only in brief fever, aching, vomiting, diarrhoea and leukopenia. ${ }^{173}$ During an epidemic, $15 \%$ of persons were infected with ECHO virus 4 . 
Half of the attacks were inapparent, minor illness predominated and a few had mild encephalitis. ${ }^{174}$ ECHO-9 virus was implicated as a cause of acute glomerulonephritis in two brothers. 175 Current knowledge contained in 181 publications about Coxsackie and ECHO viruses was summarized. ${ }^{176}$

\section{Miscellaneous viral infections}

Enteroviruses isolated from thirty-eight infants with diarrhoea and not present in healthy ones suggested that they caused infantile viral dysentery. 177 Rubeola, varicella, para-influenza, RS, and adenoviruses were associated with otitis media in $23 \%$ of 106 cases. No mycoplasma were isolated. The attack rate of Type 1 poliomyelitis among Marshall Island children in 1963 exceeded eighty-five per 1000 . The known date of its arrival established the average incubation period as 9 days, the shortest 4 days in unimmunized natives. ${ }^{178}$ Dengue occurs in diverse clinical forms as breakbone fever, haemorrhagic fever and as a mild exanthem. ${ }^{179}$ The presence of inclusions in glial cells suggested a virus to be the cause of subacute sclerosing leukoencephalitis. ${ }^{180}$

Disease resembling kuru among natives of New Guinea ensued in chimpanzees 18-21 months after intracerebral inoculation of brain tissue from patients as evidence of a 'slow' chronic viral infection. ${ }^{181}$ Adams demonstrated inclusion bodies of measles in victims of multiple sclerosis. Knowledge about slow, latent and temperate viral infections was summarized in a monograph. ${ }^{182} \mathrm{~A}$ résumé about viruses also was published. ${ }^{183}$

Viral contaminants of animal cells in tissue culture confuse diagnostic studies. A simian renal cell culture infected with SV40, SV5 and measles viruses also was susceptible to poliovirus. ${ }^{184}$

\section{Viruses and tumours}

According to Hilleman, extensive investigations on the immunology of cancer have failed to yield any procedure of significant application to man. 'The main problems of cancer still remain: Find the cause and find the cure.'185 Another review shows how obscure the problem is. ${ }^{186}$ No evidence of viral tumour-inducers was detected in neoplastic tissues from thirty-two cancers in man.187 Cytomegalovirus was present in eleven of thirty-two patients with neoplasms, but none in seventeen healthy persons. In most cases the virus probably was inactive or caused inapparent infection. ${ }^{188}$ The virus caused death in three leukaemic children. ${ }^{189}$ There is no evidence that adenoviruses are oncogenic in man. 190

Electron microscopy of a virus obtained from a Burkitt lymphoma suggested its relationship to the herpes virus group. ${ }^{191}$ Herpes simplex virus, an agent related to reovirus, and two others were isolated from eight patients. ${ }^{192}$ The variety suggests that they may have been commensals. On the other hand, a noncarcinogenic virus, like other irritants, may incite malignancy. 193 Lymphoma similar to the Burkitt type was observed in the United States. 194 Particles resembling murine leukaemia virus were seen in tissues from leukaemic children and their pet dogs, ${ }^{195}$ but also from patients with hepatitis and from normal persons. They were said to be platelet granules. ${ }^{196}$ No virus was isolated from leukaemic cells grown in tissue culture. 197

Because Langat and Kyasanur viruses cause leukopenia, they were inoculated into patients with leukaemia and cancer for their possible oncolytic effect, but transient therapeutic benefit occurred in only four of twenty-eight patients. 198 1-Adamantanamine prevented the penetration of animal sarcoma viruses and inhibited their growth in vitro. 199

Infections in lymphomas usually occurred late in the disease. Bacterial sepsis was the commonest, infections by viruses and fungi occurred less often. The outcome of disease with or without infection was similar. 200 In another report, fever occurred in $50 \%$ of 137 patients with Hodgkin's disease, but was caused by infection in only nine, usually in the terminal period. Antimicrobic therapy rarely is indicated.201 At necropsy, one patient with? Hodgkin's disease had herpetic esophagitis, pulmonic cytomegalovirus infection, toxoplasmosis and sarcocystic invasion. 202

\section{Bacillary infections}

As reported at the May 1966 meeting of the Association of American Physicians, vaccination prevented illness only when volunteers had ingested small numbers of $S$. typhosa. Apparently, vaccination prevents 'light' infections such as would occur from polluted water. Except for known exposure to typhoid or to a carrier, for institutional outbreaks and travel in endemic areas, vaccination is not needed in the U.S.A. The value of paratyphoid $A$ and $B$ vaccines has not been established. 203

Refractoriness to endotoxins in typhoid and in tularaemia induced in volunteers did not mitigate fever or toxaemia. Sustained endotoxaemia therefore is not responsible for the continuous illness in either disease. Other mechanisms as in nonendotoxin containing microbes probably are operative. 204

Salmonellar disease usually is caused by ingesting contaminated food, but infection may spread undetected from person to person afterward. Among 100 senile persons, salmonellas were 
isolated from forty-five. Only nine were sick, the rest were inapparently infected or were carriers. Antibody developed in only four of seven patients with enteritis and in about a third of the symptomless carriers. Serologic surveys evidently are not of much value to detect mild or inapparent infections or carriers. ${ }^{205}$ Antimicrobic therapy prolonged the excretion of $S$. typhimurium in infected children, as compared with untreated ones. The suppression of normal enteric flora by therapy may favour the persistence of Salmonella. ${ }^{206}$

The failure of cholecystectomy to eradicate the carrier state was ascribed to the persistence of $S$. typhosa in the liver. Prolonged therapy with ampicillin and probenicid also was unsuccessful. ${ }^{207}$ Prophylaxis, specific therapy of salmonellar infections and the control of carriers still fall short of perfection. The problems are discussed in two articles and an editorial in the British Medical Journal of 3 September 1966.

\section{Bacillary dysentery}

Thirty sporadic cases of bacillary dysentery and two deaths in adults were observed in 4 years in a hospital in Florida. Aside from diarrhoea, abdominal pain and fever, no other evidence was helpful in clinical diagnosis. Antimicrobic therapy failed to influence the course of disease.208

Urethritis, conjunctivitis and polyarthritis (Reiter's syndrome) ensued 7-10 days after attacks of bacillary dysentery in nine of 602 sailors with dysentery on shipboard. The symptoms were uninfluenced by antimicrobic, antihistaminic, and steroid therapy, and persisted for 3 months in some victims. ${ }^{209}$

Bacteria probably cause $50 \%$ of infantile diarrhoea in the United States, the rest are of viral or of unknown origin. Among forty sick infants, coxsackie, ECHO and polioviruses were isolated and specific serologic responses were detected. No virus was recovered from well babies. 177

\section{Cholera}

Despite warnings, ${ }^{210}$ there is little danger of cholera spreading to regions where hygienic conditions exist. It is one of the easiest diseases to prevent and the most satisfactory to treat. An epidemic of cholera-like disease affected a Mexican village. ${ }^{211}$ If it actually were cholera, it was its first natural appearance in the Americas for many years. In the United States, two technicians were accidentally infected in a laboratory. The enteric mucosa was normal except for hyperaemia and degeneration of the capillary endothelium.212 Cholera was induced in a volunteer who ingested a filtrate of $V$. cholerae ${ }^{213}$ suggesting that a toxin causes the symptoms. Cholera induced in guinea- pigs also suggested that a toxin accounts for cardiac, hepatic and renal disturbance. ${ }^{214}$ Choleralike disease was induced in dogs fed with vibrios. ${ }^{215}$ The proceedings of a cholera research symposium in Honolulu, January 1965, were published. 216, 217

El Tor and 'classic' cholera are identical clinically. ${ }^{218}$ That a toxin probably alters enteric mucosal permeability, that vibrios cannot be seen in the uninjured mucosa, that rapid rehydration is essential, that cholera vaccine is of doubtful value and that inapparent infections and healthy carriers occur, were discussed at a conference. ${ }^{219}$ Most of these facts, including the use of fenestrated pallets for the passage of stools, were described and illustrated in 1946.220 The need to restore water and salt in the blood was known in 1832 . One suggestion at that time was to plug the rectum with beeswax to prevent the loss of fluid.221

Extensive studies on the treatment of cholera were described in six papers in the March 1966 issue of the Bulletin of the Johns Hopkins Hospital and elsewhere. ${ }^{222}$ No significant new facts emerged. Proper rehydration with $2: 1$ salinelactate solution saved almost all lives. Tetracycline, like streptomycin ${ }^{220}$ and other antibiotics, eliminated vibrios from the stool during its administration, and was said to reduce the volume and duration of diarrhoea.

\section{Tuberculosis}

Among nearly 3000 medical students observed for 23 years, 904 had reacted to the tuberculin test on first examination. Of these thirty-one (3.4\%) later had overt tuberculosis, three had pleurisy and one died. ${ }^{223}$ Tuberculous peritonitis often is difficult to diagnose because of its disparate manifestations. A history of exposure to tuberculosis, its presence elsewhere in the body and the nature of the exudate are helpful in diagnosis. Proof depends upon peritoneoscopy, biopsy or laparotomy and the demonstration of bacilli in the tubercles. The tuberculin skin test is unreliable for diagnosis. ${ }^{224}$ Ethambutol, despite its toxicity, appears to have a role in the initial treatment and the retreatment of tuberculosis unresponsive to other drugs. 225

In a 14-year study of persons vaccinated with BCG vaccine, almost three-fourths of tuberculosis occurred in initial reactors to tuberculin. Among non-reactors, infection was reduced only $14 \%$ by vaccination. The net reduction of tuberculosis among 64,000 persons was about $5 \%$ which hardly justifies the procedure. Perhaps chemoprophylaxis with isoniazed or other drugs will be more successful.226

From world-wide sources, the incidence of tubercle bacilli primarily resistant to antimicrobics 
varied from $2 \cdot 6 \%$ to $38 \cdot 9 \%$. Drug-resistant bacilli from a treated patient may infect untreated ones or less likely may have been naturally resistant.227

It was the consensus at a panel discussion that the use of BCG vaccine should be restricted further in the United States and applied only to uninfected persons or small groups unavoidably exposed to tuberculous patients who cannot be supervised. Medical students and personnel and inmates of institutions should not be vaccinated so as not to impair the diagnostic value of the tuberculin test. 228

\section{Leprosy}

Paradoxes and misconceptions of leprosy were clarified. The diseases mentioned in the Bible were not leprosy. The infection was carried from the Old World to the New in contrast to syphilis. Susceptibility of the host determines infection of this 'highly contagious' disease but most persons are resistant. Neural and dermal leprosy always occur together. Digits never 'drop off'. Chaulmoogra oil, unless given in large doses, is useless and the term Hanson's disease should be discarded. ${ }^{229}$ M. leprae, demonstrated in the skin of normal persons in contact with leprosy, 230 indicated a carrier state or inapparent or latent infection. Vaccination of Ugandan children with BCG seemed to prevent leprosy. The incidence of infection was reduced to one-fifth of the expected rate. ${ }^{231}$ Years of observation will be needed for final evaluation of the procedure. A combination of streptomycin and sulphones was more effective for treatment than either drug alone. ${ }^{232}$

\section{Other bacillary infections}

Viable Brucella inoculated in volunteers in small amounts as a vaccine caused no fever or illness and specific agglutinin appeared after 9 months. Large numbers $(20,000)$ caused febrile illness and specific agglutinin appeared in 3 weeks. Vaccination was not recommended. 233

In Iowa, eighteen cases of diphtheria occurred in September 1962, with one death. Four families accounted for twelve of the cases and forty-eight persons were found to be carriers. No carriers were detected in a survey 1 year later. ${ }^{234}$

Because of allergic reactions and occasional failure to prevent tetanus, the use of antitoxin of animal origin is no longer desirable. Antitoxin of human origin 235 and tetanus toxoid are preferable. Peripheral neuropathy followed the injection of toxoid in one rare instance. 236

Dog ticks transmitted tularaemia to twelve children in South Dakota in an area relatively free of the disease.237 An attenuated strain of Francisella (Pasteurella tularensis), administered as an inhaled aerosol, prevented tularaemia in volunteers. ${ }^{238}$

\section{Urinary tract infections}

Urinary tract infection was twice as common in girls as in boys. Structural anomalies were present in $45 \%$ and $30 \%$ had a vesico-ureteral reflux or a bladder-neck obstruction. Most infections occurred in winter. Infection was not controlled in twenty-eight patients, many of the others had relapses usually within 3 months, often preceded by colds. 239 Only $20 \%$ of chronic urinary tract infections were cured by antimicrobic therapy. Recurrences were caused by the original bacteria or by new invaders. Antimicrobic therapy should be guided by identification of the pathogens. ${ }^{240}$

Factors other than the presence of bacteria in the kidney may cause pyelonephritis as demonstrated in seven of eighty juvenile diabetic patients. No correlation was found between bacilluria, bacteria in the kidney and the histologic evidence of pyelonephritis. ${ }^{241}$

The proper hydrogen-ion concentration in the urine is important for the antibacterial activity of drugs. The penicillins require reactions in the acid range while kanamycin and streptomycin act best in alkaline urine. Disregard of the $\mathrm{pH}$ at times may account for the failure of treatment of urinary tract infections. ${ }^{242}$ The hydrogen-ion concentration is optimal for the growth of colon bacilli in most pregnant women. ${ }^{243}$

Tetracycline given prophylactically after instrumention of the urinary tract did not reduce the incidence of bacteriuria. Many such infections are self-limiting and need no therapy. ${ }^{244}$ Tetracycline effectively sterilized the urine of rats with pyelonephritis induced by $E$. coli, but infection persisted in the kidneys of $78 \%$. The addition of streptomycin was not helpful. Ampicillin and penicillin were less effective. Evidently, renal infection may persist after the urine is cleared of bacteria. 245

\section{Coccal infections}

In one study, the home not the school was the major locus of haemolytic streptococcal infections and the source of spread to a community. ${ }^{246}$ Among 8000 cultures from the nose and throat of patients less than 18 years old, group $A$ haemolytic streptococci were present in only $6.4 \%$, and in $15 \%$ of children with exudative tonsillitis. ${ }^{247}$ Renal lesions after haemolytic streptococcal infection are not as benign as previously believed. According to biopsy evidence, about one-third of patients had renal abnormalities afterward.248 In another study, in six of twenty-one patients, biopsy and electron microscopy 20 months later disclosed changes in the mesangium. In ten others the residual changes were less severe. ${ }^{249}$ 
Because of higher living standards, improved medical care, new drugs and streptococcal control, deaths from scarlet fever, streptococcal pharyngitis and erysipelas have dropped $93 \%$ in 25 years Deaths from rheumatic fever and rheumatic cardiac disease were reduced $38 \%$, but exceed those caused by tuberculosis and syphilis.250 Antistreptococcal prophylaxis apparently can be discontinued with safety for adolescents who have had no recurrent rheumatic fever 3-5 years after a known attack. 251

Penicillinase-producing staphylococci and haemolytic streptococci were present in $28 \%$ of children with upper respiratory tract infections. There was no evidence that therapy against these staphylococci had any greater value than the one of penicillins against the streptococci. ${ }^{252}$ Deliberate implantation and colonization of avirulent staphylococci for protection against invasion by virulent ones was unsuccessful in adults. ${ }^{253}$

Staphylococci may become antimicrobic resistant in the body by transduction from resistant strains. Such genetic transmission of resistance probably occurred in addition to selection of resistant strains even before the general use of antimicrobics. ${ }^{254}$

Sixty-one per cent of septicaemias among 512 patients occurred in infants and in old age. About half of the aged victims had chronic debilitating diseases. Staphylococci and Gram-negative bacilli were the chief causes. The incidence of septicaemia has increased since 1955 mostly caused by infection with Gram-negative bacilli, the mortalityrate of which remains the same, while that of staphylococcal septicaemias has diminished.255

The death-rate from bacterial pneumonias declined from seventy to twenty-five per 100,000 between 1940 and 1950 . The rate has not changed much to date and ranged between twenty per 100,000 in 1954, the lowest, to twenty-eight per 100,000 in 1957, 1960 and 1963. About 60,000 deaths from pneumonia occur annually in the United States, mostly in infants and in old age. ${ }^{256}$

So far, eighteen instances of pneumonia caused by tetracycline-resistant pneumococci of Types 6 , $7,9,11$ and 14 were observed, mostly in persons older than 60 years. One patient with Type 14 infection died during treatment with tetracycline. ${ }^{257}$

Gram-negative bacilli caused $3 \cdot 7 \%$ of 'primary' pneumonias in a hospital. In four cases, Gramnegative bacilli superinvaded pneumococcal infection. Among thirty-eight others, Klebsiella was associated with twelve, colon bacilli with ten, Pseudomonas with seven, Bacteroides with four, Proteus with three, and $H$. influenzae and Achromobacter with one each. Seventy-four per cent of patients were between 40 and 70 years old. Other chronic diseases was present in thirty-six of thirty-eight. Leukocytosis occurred in most cases and seventeen (45\%) were fatal. Antibiotic therapy was not very effective. ${ }^{258}$ Pneumococci and influenza bacilli were the chief causes of otitis media in children. Cultures made from aspirated otitic fluid were more reliable for diagnosis than those from the oro-nasopharynx. ${ }^{259}$ As cited previously, viruses were associated in $23 \%$ of cases.

\section{Meningitis}

As in 1964, meningococcal meningitis in 1966 caused epidemics among military recruits. Antimicrobic prophylaxis failed and the installations had to be closed to stop the outbreaks.260 Gammaglobulin had no prophylactic value. ${ }^{261}$ In twentyeight cases of meningococcal meningitis, the cocci in $40 \%$ resisted sulphadiazine. Penicillin alone was curative. 262 About $16 \%$ of new recruits at one Air Force Base were carriers of meningococci, chiefly of group B. Of these, $15 \%$ resisted sulphadiazine. ${ }^{263}$ Two cases of pneumococcal meningitis were induced probably by contaminated needles during myelography. ${ }^{264}$ A 47-year-old woman had eleven attacks of meningitis in 18 years caused by Types 8, 14, 24 and 29 pneumococci, without evidence of residual injury. Higher numbered types caused similar recurrences in thirty-seven other cited cases with a low death-rate. ${ }^{265}$ One wonders whether or not the pneumococci were commensals or opportunistic invaders.

Corticosteroid therapy was deemed necessary in only ten of 159 victims of tuberculous meningitis with cerebral or pulmonic oedema, or overwhelming infection. Surprisingly intrathecal chemotherapy and PPD were applied, ${ }^{266}$ probably as measures of desperation.

Five children had meningitis caused by $N$. subflava. Four other cases were cited ${ }^{267}$ but one was omitted.268 In two cases, Proteus mirabilis was the cause, ${ }^{269}$ and in two others Mima polymorpha. 270

Combinations or successive infections with Strep. fecalis, staphylococci, coliforms, Pseudomonas, Proteus and influenza bacilli caused meningitis in forty-three patients with underlying cranial disease or after surgical intervention. Some were regarded as contaminant commensals. Antimicrobic therapy was successful in eight cases. 271 Three patients with eosinophilic meningitis were observed in Guam. The infection was first described in 1948, and Angiostrongylus cantonensis, a nematode parasite of rats and molluscs, was suspected as the cause. ${ }^{272}$

Gonococcaemia may occur without urethritis, especially in women, who often are symptomless 
carriers. ${ }^{273}$ With the increased incidence of gonorrhoea in recent years, there has been an increase of gonorrhoeal conjunctivitis. ${ }^{274}$ The instillation of $1 \%$ solution of silver nitrate still is advocated for the prevention of gonorrhoeal ophthalmia neonatorum. Penicillin is not recommended because of its sensitizing property nor are broad-spectrum antibiotics. ${ }^{275} \mathrm{~A}$ single injection of 2.4 million units of procaine penicillin, or of tetracycline in penicillin-sensitive patients, gave a 'cure-rate' of $97.9 \%$ of gonorrhoeal urethritis. Respository penicillin increased the incidence of treatment failures to $5.9 \%$; and according to other observers, the failure rate ranged from $11 \%$ to $37 \%$ after treatment with the new orally administered semisynthetic penicillins. Because microbes of the tribe Mimeae were not encountered in 350 patients, the authors doubted their clinical significance. 276

A T-strain of mycoplasma isolated from $70 \%$ of patients with nongonococcal urethritis was suspected as the cause. It was present in $13 \%$ of normal persons. ${ }^{277}$ Bedsonia also have been implicated as a cause.

\section{Endocarditis}

Despite general advice to the contrary, 278, 279 huge doses of antimicrobics were recommended as prophylactic agents during and after cardiac surgery. ${ }^{280}$ When penicillin fails to cure enterococcal endocarditis, erthromycin or bacitracin are needed. ${ }^{281}$ Ampicillin may prove to be the drug of choice with or without streptomycin. ${ }^{282}$ Staphylococcal endocarditis had increased six-fold in a hospital since 1953. The cocci usually resisted penicillin, but often were controlled with semisynthetic penicillins given for 6 weeks. ${ }^{283}$ The fifth case of endocarditis caused by Mimea was described. ${ }^{284}$ Endocarditis caused by the experimental inoculation of coxsackie B4 virus suggests that some instances of endocarditis in man may be caused by viruses. ${ }^{169}$ The subject of endocarditis in the antimicrobic era was reviewed in the 28 January, 3, 10 and 17 February issues of the New England Journal of Medicine.

\section{Mycoses}

\section{Histoplasmosis}

Erythema multiforme and erythema nodosum occurred in thirty victims during the 1962 epidemic of histoplasmosis in Iowa. Pulmonic lesions preceded dermal erythema in ten. Dermal lesions in some instances were thought to represent the primary site of infection. ${ }^{285} \mathrm{~A}$ second epidemic arose in 1964 after disturbing the soil of the same starling-roost area and 280 cases were reported. Wind-borne fungus chiefly infected children in down-wind schools, and was present on the roofs of adjacent buildings. ${ }^{286}$ Histoplasmosis may occur in early infancy. ${ }^{287} \mathrm{H}$. capsulatum caused chronic meningitis and symptomless endocarditis. The histoplasmin test gave a negative result. ${ }^{288}$ Localized dermal infection followed an accidental puncture of the skin in a laboratory worker. 289 Many victims with early pulmonary histoplasmosis recover spontaneously. Surgical excision or therapy with amphotericin is needed only for severe infections. 290 A dual infection with $H$. capsulatum and $C$. immitis was reported. Amphotericin was successful in therapy.291

Histoplasma usually are present on the surface of soil, but some were 25 in. below making eradication practically impossible.292 Bats harboured H. capsulatum. ${ }^{293}$ The Amazon valley like the Mississippi valley may be a major endemic site of histoplasmosis. Dermal tests with histoplasmin gave positive results in $43 \%$ of natives. 294

Mycotic infections are increasing in incidence in persons whose resistance is impaired or are receiving antimicrobics. Intravenously inserted catheters favour the invasion of Candida, ${ }^{295}$ and peritoneal dialysis induced peritoneal candidiasis. Meningitis in a leukaemic patient disappeared during therapy with amphotericin. Twenty-six other cases were cited in five of which amphotericin was given. 296 Contraceptive medication favours the development of vaginal candidiasis and balanoposthitis ${ }^{297}$ that heal when medication is stopped.298 Congenital candidiasis probably followed the aspiration of infected fluid from the maternal vagina. ${ }^{299}$ Symmers reviewed forty cases of deep mycotic infections in Britain including exotic ones of histoplasmosis, coccidioidomycosis and others. ${ }^{300}$

A sporotrichin skin test gave a positive reaction in a person who had had sporotrichosis 65 years ago.301 Inhalation of the spores of Cryptostroma corticale caused pneumonia (maple-bark not maple-syrup disease) in five persons. ${ }^{302}$

\section{Malaria}

A resident of Pennsylvania who had never visited an endemic area, nor received injections, had $P$. malariae malaria. Infection may have been transmitted from a carrier by a mosquito $(A$. quadrimaculatis) which is present in eastern United States. ${ }^{303} P$. ovale malaria became overt in a patient who had left West Africa more than a year before. The disease usually is mild and often is mistaken for a respiratory tract-infection or fever of unknown origin. ${ }^{304} P$. vivax obtained from a patient caused parasitaemia in inoculated monkeys whose resistance was impaired by splenectomy and an immunosuppressant drug. The infection then was transmitted from monkeys to 
volunteers. ${ }^{305}$ Diamino diphenylsulphone (DDS) used for leprosy was effective in the treatment of falciparium malaria.306 A newly recognized plasmodial parasite (Michina) destroyed many oysters along the Middle Atlantic coast. ${ }^{307}$

\section{Miscellaneous}

Gsell noted the decline in the incidence and mortality rates of pneumococcal, streptococcal, meningococcal, brucellar and tuberculous infections as a result of antimicrobic therapy, and of poliomyelitis and smallpox from vaccination. In contrast, no changes ensued in the incidence of many viral diseases, pertussis and shigellosis. Excepting typhoid, salmonellosis has increased as have other Gram-negative bacillary infections. The reported increase of viral hepatitis, leptospirosis, infectious mononucleosis and $Q$ fever may owe to better diagnoses. Because of the changing incidence of infections, young physicians are apt to be unaware of some formerly dangerous ones which are prevalent in primitive regions and rarely seen elsewhere. ${ }^{308}$ It is becoming more and more important to ask patients 'unde venis?' For examples, haemorrhagic fever contracted in Korea became overt and fatal in a patient in New York City. ${ }^{309}$ Bubonic plague contracted in New Mexico became overt in a fatal case in Boston. ${ }^{310}$ Another case occurred in a returnee from Vietnam. Cutaneous leishmaniasis became overt in travellers from endemic regions. ${ }^{311,} 312$ Peculiar histologic dermal changes aid in diagnosis when the microbes cannot be found. ${ }^{313}$

Diarrhoeal disease and respiratory tract infections most often of viral origin and malaria are the chief causes of illness among foreign troops in Vietnam. Dengue, scrub typhus, leptospirosis also are prevalent and about $20 \%$ of fevers are of unknown origin. ${ }^{314}$ Thirty cases of melioidosis occurred. Falciparum malaria resistant to synthetic drugs is of especial importance. A prophylactic agent DDS (diaminodiphenylsulphone) is under trial. As after the Korean conflict, there is concern about the importation of malaria into the United States and elsewhere. In 1965, 156 cases were reported.

Among ninety-six British abattoir workers, antibodies indicating previous infections were present in about half, including those of Coxiella $(28 \%)$, Brucella (12\%), leptospiras (6\%) and louping ill $(8 \%){ }^{315}$ In Ohio, evidence was detected of trichinellosis, psittacosis, $Q$ fever and brucellosis in that order. ${ }^{316}$

In one area of Ohio, $41 \%$ of cows were infected with $C$. burnetti. The microbe was present in fiftytwo of ninety samples of milk. Antibody was present in $21 \%$ of people, but only two overt cases were reported. ${ }^{317}$ Although infection usually is inapparent or mild, in a 5-year period fifty persons acquired $Q$ fever in a laboratory and half of them had pneumonia. All had been vaccinated previously. ${ }^{318}$

\section{Bedsonia}

Ornithosis-psittacosis in Scotland caused twentynine recognized cases and others probably occurred. Contact with birds was proved in only six. Person-to-person infection apparently occurred in two instances. ${ }^{319}$ Thirty patients in Germany had psittacosis, four with meningoencephalitis. Parrots were the source of infection in twenty-eight. ${ }^{320}$ Acute febrile pulmonic disease in persons exposed to birds is not always ornithosis, but may be the result of an allergic reaction to avian dust. ${ }^{321}$ Bedsonias were cultivated from the synovia, urethra and conjunctiva of five of eight victims of Reiter's disease. Complement fixation was demonstrated in five. ${ }^{322}$ Mycoplasma also has been suspected as a cause of rheumatoid arthritis. ${ }^{323}$ Both microbes may have been commensal.

Infection with Toxoplasma in adults often occurs during the use of immunosuppressive drugs and causes lymphadenopathy or miliary or localized disease. 324 In a survey of families, $35 \%$ of serums of adults had antibody for toxoplasma, but only $5 \%$ of children. Mild febrile episodes in four persons caused antibody to appear, and lymphadenopathy occurred in only one. Evidently, in families, toxoplasmosis may be inapparent and seldom is contagious.325 In searching for toxoplasmosis, the complement fixation test is not always of diagnostic value and a titre of less than $1: 512$ of the dye test has no clinical significance. 326

Chimpanzees infected with Schistosoma mansoni shed eggs constantly in faeces 6 weeks later. Eggs were in the lungs, pancreas, kidneys, small intestine, bladder and spleen. Fever and bloody diarrhoea were followed by hepatomegaly and ascites, and fibrosis ensued similar to that in man.327 Ambilhar was effective in reducing the output of eggs in adults. ${ }^{328}$

Bathers in ponds polluted by the excreta of livestock and rats may acquire leptospirosis ${ }^{329}$ as first described in 1940.330 Ten instances are known wherein dead Dirofilaria immitis were present in nodular pulmonic lesions. ${ }^{331}$ Eosinophilic lung or tropical eosinophilia in Singapore is an entity different from others in the tropics and is caused by microfilariae. 332

According to studies reported at the May 1966 meeting of the Association of American Physicians, unusual microbes resembling protoplasts were visualized in the lesions of Whipple's disease. 
On culture, these forms changed into streptococci. Whether they are causal or incidental must be determined.

Remnants of a bacillus, Eobacterium isolatum, the oldest known plant life, were found in 3billion-year-old rocks in Africa. ${ }^{333}$

\section{References}

1. Reimann, H.A. \& D'Ambola, J. (1966) The use and cost of antimicrobics in hospitals. Arch. environm. Health, 13, 631.

2. What should be done for a cold in the head? (1966) J. Amer. med. Ass. 196, Advertisement, page 17.

3. Hospitals report increase in Gram-negative infections. (1966) Medical News. J. Amer. med. Ass. 197, 29.

4. KARL, R.C., et al. (1966) Prophylactic antimicrobial drugs in Surgery. New Engl. J. Med. 275, 305.

5. Prophylactic antibiotics: Editorial. (1966) New Engl. J. Med. 275, 335.

6. Fletcher, C.M. \& Oldham, P.D. (1966) Value of chemoprophylaxis and chemotherapy in early chronic bronchitis. Curr. med. Dig. 33, 1429.

7. EdIE, M.B., StotT, E.J. \& Grist, N.R. (1966) Virological studies in chronic bronchitis. Brit. med. J. ii, 671.

8. GodDard A.T., FDA: New rules for the game. (1966) Science, 152, 1487.

9. RUEDY, J. (1966) A method of determining patterns of use of antibacterial drugs. Canad. med. Ass. J. 95, 807.

10. Antimicrobial agents and chemotherapy (1966) Science, 152, 108.

11. Sixth Interscience Conference on Antimicrobial Agents and Chemotherapy, Philadelphia, 26-28 October 1966.

12. TURCK, M. et al. (1966) Sodium ampicillin given parenterally. Arch. intern. Med. 117, 242.

13. Ampicillin in the treatment of pneumonia. A cooperative controlled trial (1966) Brit. med. J. i, 1329.

14. BARRETT, F.F. et al. (1966) Ampicillin in the treatment of acute suppurative meningitis. $J$. Pediat. 69, 343.

15. A new antibacterial agent. Sodium cloxacillin monohydrate (Tegopen) (1966) Council on Drugs. J. Amer. med. Ass. 195, 569.

16. LuCAS, J.B. et al. (1966) Treatment of gonorrhoea in males with cephaloridine. J. Amer. med. Ass. 195, 919.

17. KUNIN, C. \& ATUK, N. (1966) Excretion of cephaloridin and cephalothin in patients with renal impairment. New Engl. J. Med. 274, 654.

18. Kislak, J.W., Steinhauer, B.W. \& Finland, M. (1966) Cephaloridine. Activity in vitro and absorption and urinary excretion in normal young men. Amer. J. med. Sci. 251, 433.

19. Apicella, M.A., Perkins, R.L. \& SAslaw, S. (1966) Cephaloridin treatment of bacterial infections. Amer. J. med. Sci. 251, 266.

20. Thoburn, R., Johnson, J.E. \& Cluff, L.E. (1966) Studies on the epidemiology of adverse drug reactions. J. Amer. med. Ass. 198, 345.
21. Smith, J.W., Seidle, L.G. \& Cluff, L.E. (1966) Studies on the epidemiology of adverse drug reactions. Ann. intern. Med. 65, 629. BeATTY, H.N. \& PeTERSDORF, R.G. (1966) Ann. intern. Med. 65, 641.

22. Apicella, M.A., Perkins, R.L. \& Saslaw, S. (1966) Treatment of bacterial endocarditis with cephalosporin derivatives in penicillinallergic patients. New Engl. J. Med. 274, 1002.

23. FinLand, M. (1966) Summary of the conference on kanamycin: Appraisal after eight years of clinical application. Ann. N.Y. Acad. Sci. 132, 1045.

24. BARber, M. \& WATERWORTH, P.M. (1966) Activity of gentamycin against pseudomonas and hospital staphylococci. Brit. med. J. i, 203.

25. BREESE, B.B., Disney, F.A. \& Talpey, W.B. (1966) B-Hemolytic streptococcal illness. Amer. J. Dis. Child. 112, 21.

26. Petersdorf, R.G. \& Sherris, J.C. (1966) Methods and significance of in vitro testing of bacterial sensitivity to drugs. Amer. J. Med. 39, 766.

27. FOSTER, F.P. (1966) Peritonitis: A plan when treatment fails. Med. Clin. N. Amer. 50, 551.

28. A new agent for the treatment of candidal vaginitis (1966) J. Amer. med. Ass. 196, 1144. A topical agent for the treatment of superficial fungal infections of the skin (1966) $J$. Amer. med. Ass. 196, 1145.

29. SMith, J.W., Johnson, J.E. \& ClufF, L.E. (1966) Studies on the epidemiology of adverse drug reactions. New Engl. J. Med. 274, 998.

30. KaHN, M.Y. \& Hall, W.H. (1966) Staphylococcal enterocolitis-treatment with oral vancomycin. Ann. intern. Med. 65, 1.

31. Septicemia in the newborn: Editorial. (1966) J. Amer. med. Ass. 197, 215.

32. PierCe, A.K. et al. (1966) An analysis of factors predisposing to Gram-negative bacillary necrotizing pneumonia. Amer. Rev. resp. Dis. 94, 343.

33. SEeLIG, M.S. (1966) The role of antibiotics in the pathogenesis of candida infections. Amer. J. Med. 40, 887.

34. LaI, M., Rosner, F. \& Ritz, N.D. (1966) Hemolytic anemia due to antibodies to penicillin hypersensitivity. J. Amer. med. Ass. 198, 483.

35. Oldstone, M.B.A. \& Nelson, E. (1966) Central nervous system manifestations of penicillin toxicity in man. Neurology (Minneap.), 16, 693.

36. SHAw, E.B. (1966) Transverse myelitis from injection of penicillin. Amer. J. Dis. Child. 111, 548. KNOWLES, J.A. (1966) Accidental intraarterial injection of penicillin. Amer. J. Dis. Child. 111, 552.

37. Resnick, S.S. \& Shelley, W.B. (1966) Penicilloyl-polylysine skin test: anaphylaxis in absence of penicillin sensitivity. J. Amer. med. Ass. 196, 740.

38. Chung, N., Giles, C.L. \& GregG, R.H. (1966) Optic neuritis and chloramphenicol. Amer. J. Dis. Child. 112, 46.

39. RoGers, A.I. et al. (1966) Neomycin-induced steatorrhea. J. Amer. med. Ass. 197, 185.

40. Kirton, V. \& Munro-Ashman, D. (1966) Contact dermatitis from neomycin and framycetin. Lancet, i, 139. 
41. Watanabe, T. (1966) Infectious drug resistance in enteric bacteria. New Engl. J. Med. 275, 888. SMITH, D.H. \& ARMOUR, S.E. (1966) Transferable $\mathbf{R}$ factors in enteric bacteria causing infections of the genitourinary tract. Lancet, ii, 15.

42. Smith, H.W. \& Halls, S. (1966) Observation on infective drug resistance in Britain. Brit. med. J. i, 266.

43. Kabins, S.A. \& COHEN, S. (1966) Resistance transfer factor in enterobacteriacae. New Engl. J. Med. 275, 248.

44. SMitH, D.H. (1966) Salmonella with transferable drug resistance. New Engl. J. Med. 275, 625.

45. Gill, F.A. \& Hook, E.W. (1966) Salmonella strains with transferable antimicrobial resistance. J. Amer. med. Ass. 198, 1267.

46. MCDONALD, S. (1966) Transduction of antibiotic resistance in Staphylococcus aureus. Lancet, ii, 1107.

47. Rimoin, D.L. \& WenNBerg, J.E. (1966) Acute septic arthritis complicating rheumatoid arthritis. J. Amer. med. Ass. 196, 617.

48. Ayeliffe, G.A. et al. (1966) Post-operative infection with Pseudomonas aeruginosa in a hospital. Lancet, i, 1113.

49. MOORE, B. \& Forman, A. (1966) An outbreak of urinary Pseudomonas aeruginosa infection acquired during urological operations. Lancet, ii, 929.

50. Phillips, I. \& Spencer, G. (1965) Pseudomonas aeruginosa: Cross-infections due to contaminated respiratory apparatus. Lancet, ii, 1325.

51. SUTTER, V.L. et al. (1966) Source and significance of Pseudomonas aeruginosa in sputum. $J$. Amer. med. Ass. 197, 854.

52. EickHOFF, T.C., Steinhauer, B.W. \& Finland, M. (1966) Th e Klebsiella-EnterobacterSerratia division. Ann. intern. Med. 65, 1163.

53. Rose, H.D. \& KoCH, M.L. (1966) Hospital acquired Aerobacter cloacae infections. Arch. intern. Med. 117, 92

54. Weil, A.J., Ramchand, S. \& Arias, M.E. (1966) Nosocomical infection with Klebsiella type 25. New Engl. J. Med. 275, 17.

55. MCCORMaCk, R.C. \& Kunin, C.M. (1966) Control of single source nursery epidemic due to Serratia marcescens. Pediatrics, 37, 750.

56. Magnuson, C.W. \& Elston, H.R. (1966) Infections caused by nonpigmented Serratia. Report of seven cases. Ann. intern. Med. 65, 409.

57. Clayton, E. \& von Graevenitz, A. (1966) Nonpigmented Serratia marcescens. J. Amer. med. Ass. 197, 1059.

58. Cohen, P. \& GARdner, F.H. (1966) Thrombocytopenia as a laboratory sign and complication of Gram-negative bacteremic infection. Arch. intern. Med. 117, 113.

59. Kanich, R.E. \& Craighead, J.E. (1966) Cytomegalovirus infection and cytomegalic inclusion disease in renal homotransplant recipients. Amer. J. Med. 40, 872.

60. RifKIND, D., FARIS, T.D. \& Hill, R.B. (1966) Pneumocystis carinii pneumonia. Ann. intern. Med. 65, 943.

61. Cruz, T., Reboucas, G. \& Rocha, H. (1966) Fatal strongyloidiasis in patients receiving corticosteroids. New Engl. J. Med. 275, 1093.

62. Increase in Colds Boosts U.S. Total of Acute Illness (1966) Mod. med. News, 6, 20.
63. GWaltney, J.M. \& JoRdan, W.S. (1966) Rhinoviruses and respiratory illnesses in university students. Amer. Rev. resp. Dis. 93, 362.

64. HeROUT, V., VORTEL, V. \& VONDRACKOVA, A (1966) Herpes simplex involvement of the lower respiratory tract. Amer. J. clin. Path. 46, 411.

65. PereirA, M.A. et al. (1966) Ryan virus: A possible new human pathogen. Brit. med. J. i, 130.

66. PORTNOY, B. et al. (1966) The perepheral white blood count in respirovirus infection. $J$. Pediat. 68, 181.

67. Douglas, R.G. et al. (1966) A study of the mechanism of accumulation of Rhinovirus nasal secretion antibody, Program. Amer. Soc. clin. Invest. 2 May 1966, p. 30.

68. LeFKOWITZ, L.B. \& JACKSON, G.G. (1966) Dua respiratory infection with para-influenza and Rhinovirus. Amer. Rev. resp. Dis. 93, 519.

69. Mascoli, C.C. et al. (1966) Attempt at immunization by oral feeding of live rhinoviruses in enteric coated capsules. Proc. Soc. exp. Biol. (N.Y.), 121, 1264.

70. ANDREWES, C.H. (1966) Rhinoviruses and common colds. Ann. Rev. Med. 17, 361 .

71. BROWN, A.J. (1966) Evaluation of an influenza immunization program. Arch. environm. Health, 12, 597.

72. Wendell, H.A., Snyder, M.T. \& Pell, S. (1966) Trial of amantidine in epidemic influenza. Clin. pharmacol. Ther. 7, 38.

73. Quilligan, J.J., Hirayama, M. \& BaERnStein, H.D. (1966) The suppression of A2 influenza in children by the chemoprophylactic use of amantidine. J. Pediat. 69, 572.

74. Alford, R.H. et al. (1966) Human influenza resulting from aerosol inhalation. Proc. Soc. exp. Biol. (N.Y.), 122, 800.

75. SMITH, C.M. et al. (1966) Protective effect of antibody to para-influenza type 1 virus. New Engl. J. Med. 275, 1145 .

76. Tateno, I., Kitamoto, O. \& Kawamura, A. (1966) Diverse immunocytologic findings of nasal smears in influenza. New Engl. J. Med. 274, 237.

77. Hamre, D. \& Procknow, J.J. (1960) A new virus isolated from the human respiratory tract. Proc. Soc. exp. Biol. (N.Y.), 121, 190.

78. Couch, R.B. et al. (1966) Aerosol-induced adenoviral illness resembling the naturally occurring illness in military recruits. Amer. Rev. resp. Dis. 93, 529.

79. EDMONDSON, W.P. et al. (1966) Immunization by selective infection with type 4 adenovirus grown in human diploid tissue culture. $J$. Amer. med. Ass. 195, 453.

80. BANKS, P.A. et al. (1966) Persistence of neutralizing antibody in adult volunteers immunized with adenovirus soluble antigens. Proc. Soc. exp. Biol. (N.Y.), 121, 240.

81. Bauer, D.J. \& Apostolov, K. (1966) Adenovirus multiplication: inhibition by methisazone. Science, 154, 796.

82. BuTEL, J.S. et al. (1966) Replication of adenovirus type 7 in monkey cells: a new determinant and its transfer to adenovirus type 2 . Science, 154, 671.

83. Dreisin, R.S. et al. (1966) Clinical course of respiratory infection caused by respiratory syncytial virus. Pediatriya, 45, 23. 
84. Field, C.M.B. et al. (1966) Antibiotic treatment of epidemic bronchiolitis-a double-blind trial. Brit. med. J. i, 83.

85. Potash, L. et al. (1966) Respiratory virus vaccines. Amer. Rev. resp. Dis. 93, 536.

86. KIM, H.W. et al. (1966) Immunogenicity of inactivated para-influenza Type 1 , Type 2 , and Type 3 vaccines in infants. J. Amer. med. Ass. 196, 819.

87. WeIBEL, R.E. et al. (1960) Respiratory virus vaccines. V. Field evaluations for efficacy of heptavalent vaccine. Amer. Rev. resp. Dis. 94, 362.

88. Hilleman, M.R. (1966) Vaccine, chemotherapy, and host resistance approaches to control of viral respiratory disease. Manitoba med. Rev. 46, 200.

89. LEERS, W.D. \& ROZEe, K.R. (1966) Survey of reovirus antibodies in sera of urban children. Canad. med. Ass. J. 1, 83.

90. ReimanN, H.A., Havens, W.P. \& Price, A.H. (1942) Etiology of atypical ('virus') pneumonias. Arch. intern. Med. 70, 513. REIMANN H.A. (1943) Viral pneumonias. Bull. N.Y. Acad. Med. 19, 177.

91. Foy, H. et al. (1966) Epidemiology of mycoplasma pneumoniae infection in families. $J$. Amer. med. Ass. 197, 859.

92. Alexander, E.R. et al. (1966) Pneumonia due to mycoplasma pneumoniae. New Engl. J. Med. 275, 131 .

93. JAO, R.L., Rubenis, M. \& JACKSON, G.G. (1966) Isolation of Mycoplasma pneumoniae from adults with respiratory infection. Arch. intern. Med. 117, 520.

95. MetzGaR, D.P. et al. (1966) Respiratory virus vaccines. II. Mycoplasma pneumoniae (Eaton agent) vaccines. Amer. Rev. resp. Dis. 94, 1.

94. SussmaN, S.J. et al. (1966) Cold agglutinins, Eaton agent, and respiratory infection of children. Pediatrics, 38, 571.

96. Brody, J.A., Alexander, E.R. \& Hanson, M.L. (1966) Measles vaccine field trials in Alaska. J. Amer. med. Ass. 196, 757.

97. Furesz; J. \& HABgoOd, M. (1966) Vaccination against measles in the Canadian Arctic. $J$. Amer. med. Ass. 195, 342.

98. Allen, H.S., Talbot, W.H. \& MCDonald, R.M. (1966) Atypical lymph-node hyperplasia after administration of attenuated, live measles vaccine. New Engl. J. Med. 274, 677.

99. Dorfman, R.F. \& Herwig, J.C. (1966) Live attenuated measles virus vaccine, inguinal lymphadenopathy complicating administration. J. Amer. med. Ass. 198, 320.

100. Vaccination against measles, Leading Article (1966) Brit. med. J. i, 435

101. Llanes-Rodas, R. \& LiU, C. (1966) Rapid diagnosis of measles from urinary sediments stained with fluorescent antibody. New Engl. J. Med. 275, 516.

102. ChERRY, J.D. \& JAHN, C.L. (1966) Exanthem and enanthem associated with mumps virus infection. Arch. environm. Health, 12, 518.

103. ST GEME, J.W., NOREN, G.R. \& ADAMS, $P$ (1966) Proposed embryopathic relation between mumps virus and primary endocardial fibroelastosis. New Engl. J. Med. 275, 339.

104. GersonY, W.M., KATZ, S.L. \& NADAS, A.S (1966) Endocardial fibroelastosis and the mumps virus. Pediatrics, 37, 430 .
105. Meyer, M.B., Stifler, W.C. \& Joseph, J.M. (1966) Early evaluation of mumps vaccine after exposure to mumps. Pediatrics, 37, 304.

106. Live mumps vaccine found virtually $100 \%$ protective (1966) Medical News. J. Amer. med. Ass. $197,42$.

107. BRODY, J.A. (1966) The infectiousness of rubella and the possibility of reinfection. Amer. $J$. Publ. Hlth, 56, 1082.

108. HAMbridge, R.M. et al. (1960) Congenital Rubella: report of two cases with generalized infection. Brit. med. J. i, 650.

109. YaneZ, J.E. et al. (1966) Rubella arthritis. Ann. intern. Med. 64, 772 .

110. Cifarelli, P.S. \& Freireich, A.W. (1966) Rubella encephalitis. N.Y. State J. Med. 66, 1117.

111. Monif, G.R.G. \& Sever, J.L. (1966) Chronic infection of central nervous system with Rubella virus. Neurology (Minneap.), 16, 111.

112. Morse, E.E., ZinkHaM, W.H. \& JACKSON, D.P. (1966) Thrombocytopenic purpura following rubella in children and adults. Arch. intern. Med. 117, 573.

113. ReimanN, H.A. (1966) Thrombocytopenia during infectious diseases. Letter to Editor. $J$. Amer. med. Ass. 196, 460.

114. Siegel, M., Fuerst, H.T. \& Peress, N.S. (1966) Comparative fetal mortality in maternal virus diseases. New Engl. J. Med. 274, 768.

115. SEver, J.L. et al. (1966) Clinical and subclinical rubella following intradermal inoculation of rubella virus into human volunteers. Amer. $J$. Epidem. 84, 163

116. Test spots Rubella antibodies in three hours (1966) Med. Wld News, 7, 36.

117. AMar, A.D. (1966) Hematuria caused by Varicella lesions in the bladder. J.Amer. med. Ass. 196, 450.

118. CHICK, F.E. (1966) Hematuria complicating varicella. Letter to Editor. J. Amer. med. Ass. 197, 299.

119. TAUB, E.A. (1966) Renal lesions, gross hematuria and marrow granulomas in infectious mononucleosis. J. Amer. med. Ass. 195, 1153.

120. BAUM, S.G. et al. (1966) Epidemic nonmeningitic lymphocytic-choriomeningitis infection. An outbreak in a population of laboratory personnel. New Engl. J. Med. 274, 934.

121. Meyer, H.M., Parkman, P.D. \& Panos, T.C. (1966) Attenuated Rubella virus II production of an experimental live-virus vaccine and clinical trial. New Engl. J. Med. 275, 575.

122. TONDURY, G. (1965) Virus infection during pregnancy. Geburtsch. $u$. Frauenheilk, 25, 997.

123. Thelander, H.E. (1966) Letter to Editor. $J$. Amer. med. Ass. 198, 791.

124. Morse, L.J., Rubin, H.E. \& Blount, R.E. (1966) Vaccine-acquired paralytic poliomyelitis in an unvaccinated mother. J. Amer. med. Ass. 197, 1034.

125. Berkovitch, S. \& STURR, S. (1966) Effects of live type 1 poliovirus vaccine and other viruses on the tuberculin test. New Engl. J. Med. 274, 67.

126. Bishop, W.B., Carlton, R.F. \& SANDERS, L.L. (1966) Diffuse vasculitis and death after hyperimmunization with pertussis vaccine. New Engl. J. Med. 274, 616. 
127. Joint Statement. (1966) Fatal viral encephalitis following 17D yellow fever vaccine inoculation. J. Amer. med. Ass. 198, 671.

128. Green, D.M., ReID, S.M. \& Rhaney, K. (1966) Generalized vaccinia in the human foetus. Lancet, i, 1296.

129. WENTWORTH, P. (1966) Studies on placentae and infants from women vaccinated for smallpox during pregnancy. J. clin. Path. 19, 328.

130. Stickl, H. \& Helming, M. (1966) Purulent meningitis after smallpox vaccination: on the question of postvaccinal decrease of resistance to infection. Dtsch. med. Wschr. 91, 1307.

131. Thomson, D. (1966) Mass immunization in the control of infectious disease. Brit. med. J. ii, 427.

132. Hilleman, M.R. (1966) Critical appraisal of emulsified oil adjuvants applied to viral vaccines. Progr. med. Virol. 8, 131.

133. Hilleman, M.R. (1966) Adenovirus: history and future of a vaccine. Viruses Inducing Cancer, pp. 377-402. University of Utah Press.

134. RAO, A.R. \& McFADDEN, J.A. (1966) An isothiazole thiosemicarbazone in the treatment of variola major in man: Controlled chemical trial and laboratory investigations. Lancet, $\mathbf{i}$, 1068. RAO, A.R. et al. (1966) Assessment of an isothiazole thiosemicarbazone in the prophylaxis of contacts of variola major. Lancet, i, 1072. Drugs against viruses: Leading Article (1966) Brit. med. J. ii, 600.

135. Smallpox (1966) Amer. med. Ass. 9, 2.

136. REED, D. et al. (1966) Methisazone for prophylaxis against chickenpox. J. Amer. med. Ass. 195, 586.

137. Cruickshank, J.G., Bedson, H.S. \& Watson, D.H. (1966) Electron microscopy in the rapid diagnosis of smallpox. Lancet, ii, 527.

138. Lieberman, M., Polikoff, R. \& Pascale, A.M. (1966) Effect of concomitant treatment by cortisone and $\mathbf{N}$-ethylisatin $\beta$ thiosemicarbazone on neurovaccinia virus infected mice. Proc. Soc. exp. Biol. (N.Y.), 122, 484.

139. Corbetr, M.B., Sidell, C.M. \& ZimMERMAN, M. (1966) Idoxurdine in the treatment of cutaneous Herpes simplex. J. Amer. med. Ass. 196, 441.

140. Breeden, C.J., Hall, T.C. \& Tyler, H.R. (1966) Herpes simplex encephalitis treated with systemic 5-iodo- 2' deoxyuridine. Ann. intern. Med. 65, 1050.

141. RABSON, A.S. et al. (1966) Virus: mixed infection with Herpes simplex and simian virus 40 . Science, 151, 1535.

142. FurusaWa, E. \& Cutting, W. (1966) Antiviral activities of higher plants on lymphocytes choriomeningitis infection in vitro and in vivo. Proc. Soc. exp. Biol. (N.Y.), 122, 280.

143. LARKe, R.P.B. (1966) The effects of therapeutic measures in diseases caused by viruses. Canad. med. Ass. J. 95, 961.

144. Miller, J.K. (1966) Herpes simplex encephal92.

145. RAWLS, W.E. et al. (1966) Encephalitis associated with Herpes simplex virus. Ann. intern. Med. 64, 104.

146. Malkova, E.V. (1966) Meningitis and meningoencephalitis in the course of Herpes zoster. Zh. Nevropat. Psikhiat. Korsakov, 66, 189.
147. McLean, D.M. et al. (1966) Viral infections in children during 1965. II. Measles encephalitis and other complications. Canad. med. Ass. J. 94, 905.

148. Herpes simplex encephalitis: Editorial. (1966) Brit. med. J. i, 1497.

149. Gabrielson, M.V., Joseph, C. \& Hsiung, G.D. (1966) Encephalitis associated with adenovirus type 7 occurring in a family outbreak. $J$. Pediat. 68, 142.

150. Young, D.J. (1966) California encephalitis virus. Report of three cases and review of the literature. Ann. intern. Med. 65, 419.

151. HAMmON, W.M. \& SATHER, G. (1966) History and recent appearance of viruses in the California encephalitis group. Amer. J. trop. Med. Hyg. 15, 199.

152. Sulkin, S.E., Sims, R.A. \& AlleN, R. (1966) Isolation of St. Louis encephalitis from bats (Tadarida b. mexicana) in Texas. Science, 152, 223.

153. BufF, B.H. (1964) Rabies : a summary of recent contributions to the Literature (July 1958-June 1963). Med. Ann. D. C. 33, 149.

154. Dr John F. Bell tests new rabies theory in Argentina (1966) Trop. Med. Hyg. News, 15, 9.

155. Anderson, J.A., DAly, F.T. \& KiDD, J.C. (1966) Human rabies after antiserum and vaccine postexposure treatment. Ann. intern. Med. 64, 1297.

156. HildRETH, E.A. (1966) Rabies prevention: Editorial. Ann. intern. Med. 64, 1357.

157. Goals for rabies: better vaccine, control and quicker diagnosis. (1966) Medical News. J. Amer. med. Ass. 196, 32.

158. Boulger, L.R. (1966) Natural rabies in a laboratory monkey. Lancet, $\mathbf{i}, 941$.

159. The cycle of viral hepatitis (1966) Statist. Bull. Metrop. Life Insur. Co. 47, 1.

160. Viral hepatitis (1966) Medical News. J. Amer. med. Ass. 196, 42.

161. BYRNE, E.B. (1966) Viral hepatitis: an occupational hazard of medical personnel. $J$. Amer. med. Ass. 195, 362.

162. COOPER, W.C. et al. (1966): Anicteric Viral Hepatitis, Clinicopathological follow up study in Taiwan. New Engl. J. Med. 274, 585. Hepatitis in the Far East: Editorial. New Engl. J. Med. 274, 630.

163. AfFOLTER, H. (1966) Acute infectious hepatitis during the puerperium. Schweiz. med. Wschr. 96, 145.

164. Mainwaring, R.L. \& BRUECKNER, G.G. (1966) Fibrinogen-transmitted hepatitis. A controlled study. J. Amer. med. Ass. 195, 437.

165. Holland, P.V. et al. (1966) $\gamma$-Globulin in the prophylaxis of post transfusion hepatitis. $J$. Amer. med. Ass. 196, 471.

166. HARTWELl, W.V., LOVE, G.J. \& EIDENBOCK, M.P. (1966) Adenovirus in blood clots from cases of infectious hepatitis. Science, 152, 1390.

167. LAMB, S.G. \& Stern, H. (1966) Cytomegalovirus mononucleosis with jaundice as presenting sign. Lancet, ii, 1003.

168. SuN, N.C. \& SMITH, V.M. (1966) Hepatitis associated with myocarditis, unusual manifestation of infection with coxsackie virus group B, type 3. New Engl. J. Med. 274, 190.

169. BuRCH, G.E. et al. (1966) Endocarditis in mice infected with coxsackie virus $B_{4}$. Science, 151, 447. 
170. GoHD, R.S. \& FAIGeL, H.C. (1966) Hand- footand mouth disease resembling measles: a life threatening disease. Pediatrics, 37, 644 .

171. CherRY, J.D. (1966) Hand- foot- and mouth syndrome: report of six cases due to coxsackie virus group A, type 16. Pediatrics, 37, 637.

172. HJORTH, N. \& KOPP, H. (1966) Hand-footmouth disease in Copenhagen. Ugeskr. Laeg. 128, 293.

173. Johnson, K.M. \& Peralta, P.H. (1966) Clinical and serological response to laboratoryacquired human infection by Indiana type vesicular stomatitis virus (VSV). Amer. J. trop. Med. Hyg. 15, 244.

174. RAY, C.G. et al. (1966) ECHO 4 illness, epidemiological, clinical and laboratory studies of an outbreak in a rural community. Amer. J. Epidem. 84, 253.

175. YuCEOGLU, A.M., BerKovitch, S. \& MinkoWITZ, S. (1966) Acute glomerulonephritis associated with ECHO virus type 9 infection. J. Pediat. 69, 603.

176. MCLEAN, D.M. (1966) Coxsackieviruses and echoviruses. Amer. J. med. Sci. 251, 351.

177. Behbehani, A.M. \& WenNeR, H.A. (1966) Infantile diarrhoea: a study of the etiological role of viruses. Amer. J. Dis. Child. 111, 623 .

178. Peterson, C.R. et al. (1966) Poliomyelitis in an isolated population. Report of a type 1 epidemic in the Marshall Islands, 1963. Amer. J. Epidem. 82, 273.

179. Dooley, J.R. (1966) Three faces of dengue. Arch. intern. Med. 117, 170.

180. Tellez-Nagel, I. \& Harter, D.H. (1966) Subacute sclerosing leucoencephalitis: ultrastructure of intranuclear and intracytoplasmic inclusions. Science, 154, 899.

181. Gajdusek, D.C., GibBs, C.J. \& Alpers, M. (1966) Experimental transmission of a Kurulike syndrome to chimpanzees. Nature (Lond.), 209, 794.

182. Slow, latent, and temperate virus infections (1965) NINDB No. 2. U.S. Government Printing Office, Washington.

183. ISRAEL, M. (1966) Viruses. Brit. med. J. ii, 687.

184. Hsiung, G.D., Atoynatan, T. \& GluCK, L. (1966) Multiple virus infections of monkey kidney cells in culture. Proc. Soc. exp. Biol. (N.Y.), 121, 562.

185. Hilleman, M.R. (1966) Approaches to control of cancer by immunologic procedures. Proc. int. Wenner-Gren Symp., Stockholm, September 1965. Pergamon Press, Oxford.

186. BLACK, P.H. (1966) Recent advances in the study of oncogenic viruses. New Engl. J. Med. 275, 377.

187. GIRARDI, A.J. et al. (1966) Search for virus in human malignancies. 4. Tests of human neoplastic tissues in sex-segregated mice. Proc. Soc. exp. Biol. (N.Y.), 121, 428.

188. Duvall, C.P. et al. (1966) Recovery of cytomegalovirus from adults with neoplastic disease. Ann. intern. Med. 64, 531.

189. Cangir, A. \& Sullivan, M.P. (1966) The occurrence of cytomegalovirus infections in childhood leukemia. J. Amer. med. Ass. 195, 616.

190. Sultanian, I.V. \& Freeman, G. (1966) Enhanced growth of human embryonic cells infected with adenovirus 12. Science, 154, 665 .
191. Toplin, I. \& Schidlovsky, G. (1966) Partial purification and electron microscopy of virus in the EB-3 cell line derived from a Burkitt lymphoma. Science, 152, 1084.

192. BeLL, T.M. et al. (1966) Further isolation of reovirus type 3 from cases of Burkitt's lymphoma. Brit. med. J. i, 1514.

193. Etiology of Burkitt's sarcoma: Editorials. (1966) J. Amer. med. Ass. 198, 77.

194. Management of acute leukemia : a clue from Africa: Editorial. (1966) J. Amer. med. Ass. 198, 1116.

195. Animal-man cancer probes continue (1966) Medical News. J. Amer. med. Ass. 196, 30.

196. Prince, A.M. \& Adams, W.R. (1966) Virus-like particles in human plasma and serum: role of platelet lysosomes. J. nat. Cancer Inst. 37, 153.

197. ARMSTRONG, D. (1966) Serial cultivation of human leukemic cells. Proc. Soc. exp. Biol. (N.Y.), 122, 473.

198. WEBB, H.E. et al. (1966) Leukaemia and neoplastic processes treated with Langat and Kyasanur Forest disease viruses: a clinical and laboratory study of 28 patients. Brit. med. J. i, 258.

199. Wallbank, A.M., Matter, R.B. \& Klinikowski, N.G. (1966) 1-Adamantanamine hydrochloride; inhibition of Rous and Esh sarcoma viruses in cell culture. Science, 152, 1760.

200. Casazza, A.R., Duvall, C.P. \& Carbone, P.P. (1966) Infections in lymphoma. J. Amer. med. Ass. 197, 710.

201. Lobell, M., Boggs, D.R. \& Wintrobe, M.Mg (1966) The clinical significance of fever in Hodgkin's disease. Arch. intern. Med. 117 335.

202. Goodman, M. \& Maher, E. (1966) Four uncommon infections in Hodgkin's disease. J. Amer. med. Ass. 198, 1129.

203. Typhoid immunization (1966) Washington News. J. Amer. med. Ass. 197, 23.

204. Greisman, S.E. et al. (1966) The role of endotoxin during typhoid fever and tularemia in man. Program, Amer. Soc. clin. Invest. March 2, 1966, p. 45 .

205. GoTOFF, S.P., Boring, J.R. \& LEPPER, M.H. (1966) An epidemic of Salmonella St. Paul infection in a convalescent home. Amer. J. med. Sci. 251, 16. GOTOFF, S.P., LEPPER, M.H. \& FIEDLER, M.A. (1966) Immunologic studies in an epidemic of Salmonella infections. Amer. J. med. Sci. 251, 23.

206. DixON, J.M.S. (1965) Effect of antibiotic treatment on the duration of excretion of Salmonella typhimurium by children. Brit. med. J. ii, 1343 .

207. McFadzean, A.G.S. \& ONG, G.B. (1966) Intrahepatic typhoid carriers. Brit. med. J. i, 1567.

208. BARRET-ConNOR, E. (1966) Shigellosis in the adult. J. Amer. med. Ass. 198, 717.

209. NOER, H.R. (1966) An 'experimental' epidemic of Reiter's syndrome. J. Amer. med. Ass. 198, 693.

210. Cholera may soon threaten (1966) Med. Wld News, 7, 9.

211. U.S. Health Team detours to halt Mexican epidemic (1966) Med. Wld News, 7, 44.

212. SHEEHY, T.W. et al. (1966) Laboratory Vibrio cholerae infection in the United States. J. Amer. med. Ass. 197, 321. 
213. Bengajati, C. (1966) Experimental cholera in humans. Brit. med. J. i, 140.

214. Goldstein, H.A., MerRill, T.G. \& Sprinz, H. (1966) Experimental cholera. Amer. J. Path. $82,54$.

215. Cholera death toll rising despite therapeutic gains (1966) Antibiot. News, 3, 8.

216. DAMmin, G.J. et al. (1966) Clinical and histopathologic correlation in acute diarrhoeal diseases. Proc. Cholera Res. Symp, Honolulu, Hawaii. U.S. Government Printing Office, 1965 , p. 205.

217. Proceedings of the Cholera Research Symposium (1966) U.S. Department of Health, Education and Welfare, U.S. Government Printing Office, Washington, D.C.

218. Wallace, C.K. et al. (1966) Classical and $\mathrm{El}$ Tor cholera: a clinical comparison. Brit. med. J. ii, 447.

219. GoRDON, R.S. et al. (1966) Cholera, Clinical Staff Conference. Ann. intern. Med. 64, 1328.

220. ReImanN, H.A. et al. (1946) Asiatic cholera. Clinical study and experimental therapy with Streptomycin. Amer. J. trop. Med. 26, 631.

221. RosenBERG, C.E. (1962) The Cholera Years, p. 67. University of Chicago Press.

222. Phillips, R.A. (1966) Cholera in the perspective of 1966. Ann. intern. Med. 65, 922.

223. Myers, J.A., BeArman, J.E. \& Botkins, A.C. (1966) Natural history of tuberculosis in the human body. Dis. Chest, 50, 120.

224. Gonnella, J.S. \& Hudson, E.K. (1966) Clinical patterns of tuberculosis peritonitis. Arch. intern. Med. 117, 164.

225. Pyle, M.M. et al. (1966) A four year clinical investigation of ethambutol in initial and retreatment cases of tuberculosis. Amer. Rev. resp. Dis. 93, 428.

226. Comstock, G.W. \& Palmer, C.E. (1966) Longterm results of $B C G$ vaccination in the Southern United States. Amer. Rev. resp. Dis. 93, 171.

227. Primary drug resistance in tuberculosis: Leading Article. (1966) Brit. med. J. ii, 656.

228. Panel discusses BCG vaccine. (1966) Medical News. J. Amer. med. Ass. 198, Advertisement p. 49.

229. ARNOLD, H.L. (1966) Paradoxes and misconceptions in leprosy. J. Amer. med. Ass. 196, 647.

230. The leprosy puzzle: Editorials. (1966) J. Amer. med. Ass. 197, 580.

231. KinNear Brown, J.A.K., Stone, M.M. \& SUTHERLAND, I. (1966) B.C.G. vaccination of children against leprosy: first results of a trial in Uganda. Brit. med. J. i, 7.

232. Leprosy yields to TB strategy (1966) Med. Wld News, 7, 35.

233. Pappagianis, D., Elberg, S.S. \& Crouch, D. (1966) Immunization against Brucella infections: effects of graded doses of viable attenuated Brucella melitensis in humans. Amer. J. Epidem. 84, 21.

234. CoROTHERS, T.E. \& ZatLiN, G.S. (1966) Control of a diphtheria outbreak. Clin. Pediat. 5, 29.

235. Perey, B.J.R. (1966) Progress in tetanus prophylaxis: the advent of human antitoxin. Canad. med. Ass. J. 94, 437.

236. Blumstein, G.I. \& Kreithen, H. (1966) Peripheral neuropathy following tetanus toxoid administration. J. Amer. med. Ass. 198, 1030.
237. Saliba, G.S. et al. (1966) An outbreak of human tularemia associated with the American dog tick, Dermacentor variabilis. Amer. J. trop. Med. Hyg. 15, 531.

238. Aerosolized live vaccine protects against tularemia. (1966) Med. Wld News, 7, 33.

239. StANSFIELD, J.M. (1966) Clinical observations relating to the incidence and etiology of urinary tract infections in children. Brit. med. J. i, 631; Relapses of urinary tract infections in children. Brit. med. J. i, 635.

240. TurCK, M., ANDERSON, K.N. \& Petersdorf, R.G. (1966) Relapse and reinfection in chronic bacteriuria. New Engl. J. Med. 275, 70.

241. Halvorstadt, D.B., LeadbetTer, G.W. \& FIELD, R.A. (1966) Pyelonephritis in the diabetic. J. Amer. med. Ass. 195, 827.

242. Tallgren, L.G. \& VoN BonsDorfF, C.H. (1965) Effect of urine pH on antibiotics. Acta med. scand. 178, 543.

243. Asscher, A.W. et al. (1966) Urine as a medium for bacterial growth. Lancet, ii, 1037.

244. Higgins, P.M. (1966) Value of prophylactic antibacterial therapy in instrumentation of urinary tract. Brit. med. J. i, 26.

245. Lipman, R.L. et al. (1966) Evaluation of antibiotic therapy in acute pyelonephritis produced by Escherichia coli in rats. J. Lab. clin. Med. 67, 546.

246. LEVINE, J.I. et al. (1966) Studies on the transmission within families of group A streptococci. J. Lab. clin. Med. 67, 483.

247. Alpert, J.J., Pickering, M.R. \& Warren, R.J. (1966) Failure to isolate streptococci from children with exudative tonsillitis. Pediatrics, 38, 663.

248. Freedman, P. et al. (1966) The renal response to streptococcal infection. Program, Amer. Soc. clin. Invest., May 2, 1966, p. 36.

249. LANGE, R. et al. (1966) Clinical, morphologic and immunologic studies on the natural history of acute post-streptococcal glomerulonephritis. Program, Amer. Coll. Phys., April 18, 1966, p. 11.

250. Mortality from streptococcal infections and residual heart involvement (1966) Statist. Bull. Metrop. Life Insur. Co. 47, 8.

251. Feinstein, A.R. et al. (1966) Discontinuation of antistreptococcal prophylaxis. J.Amer. med. Ass. 197, 949.

252. Quie, P.G., Pierce, R.C. \& Wannamaker, L.W. (1966) Influence of penicillinase-producing staphylococci on the eradication of group A A streptococci from the upper respiratory tract by penicillin treatment. Pediatrics, 37, 467.

253. Bacterial interference: a warning (1966) Medical News. J. Amer. med. Ass. 198, Advertisement p. 40.

254. MoRSE, S.I. \& Novick, R.P. (1966) In vivo transmission of antibiotic resistance between strains of Staphylococcus aureus. Program, Amer. Soc. clin. Invest., 2 May 1966, p. 77.

255. Altemeier, W.A., TodD, J.C. \& INGE, W.W. (1966) Newer aspects of septicemia in surgical patients. Arch. Surg. 92, 566.

256. Long-term changes in pneumonia-influenza mortality (1966) Statist. Bull. Metrop. Life Insur. Co. 47, 7. 
257. SchaffNer, W., Schreiber, W.M. \& KoENiG, M.G. (1966) Fatal pneumonia due to a tetracycline-resistant pneumococcus. New Engl. J. Med. 274, 451.

258. Tillotson, J.R. \& Lerner, A.M. (1966) Pneumonias caused by Gram-negative bacilli. Medicine (Baltimore), 45, 65.

259. Feingold, M. et al. (1966) Acute otitis media in children. Amer. J. Dis. Child. 111, 361.

260. U.S. Military Bases battle meningitis (1966) Mod. Med. 6, 26.

261. SAmple, D.W. et al. (1966) The failure of gamma globulin as a prophylactic agent in meningococcal disease. Amer. J. Epidem. 84, 156.

262. PainTer, M.B. (1966) Treatment of acute meningococcal infection in adults. Ann. intern. Med. 64, 1049.

263. Farrell, D.G. \& Dahl, E.V. (1966) Nasopharyngeal carriers of Neisseria meningitidis. J. Amer. med. Ass. 198, 1189.

264. Rose, H.D. (1966) Pneumococcal meningitis following intrathecal injections. Arch. Neurol. 14, 597.

265. WhitecaR, J.P., REDDIN, J.L. \& SPINK, W.W. (1966) Recurrent pneumococcal meningitis. New Engl. J. Med. 274, 1285.

266. Hockaday, J.M. \& SMITH, H.M.V. (1966) Conticosteroids as an adjuvant to the chemotherapy of tuberculous meningitis. Tubercle (Edinb.), 47, 75.

267. LewiN, R.A. \& Hughes, W.T. (1966) Neisseria subflava as a cause of meningitis and septicemia in children. J. Amer. med. Ass. 195, 821.

268. ReimanN, H.A. \& Koucky, R.W. (1939) Meningitis caused by atypical Gram-negative cocci. J. Bact. 37, 40.

269. Scherzer, A.L., KAYE, D. \& Shinefeld, H.R. (1966) Proteus mirabilis meningitis. Two cases treated with ampicillin. J. Pediat. 68, 731.

270. Burrows, S. \& KING, M. (1966) Meningitis due to Mima polymorpha. Amer. J. clin. Path. 46, 234.

271. KEYS, T.F. et al. (1966) Bacterial meningitis. IV. Infection caused by multiple organisms. Proc. Mayo Clin. 41, 179.

272. Linaweaver, P.G. (1966) Eosinophilic meningitis. First reported cases on Guam, M.I. Milit. Med. 131, 579.

273. ACKerman, A.B. (1966) Asymptomatic gonorrhoea, the gonococcal carrier state, and gonococcemia in men. J. Amer. med. Ass. 196, 101.

274. HANSEN, T. et al. (1966) Gonorrhoeal conjunctivitis, an old disease returned. J. Amer. med. Ass. 195, 1156.

275. BARSAM, P.C. (1966) Specific prophylexis of gonorrhoeal opthalmia neonatorum. A $\mathbf{R e}$ view. New Engl. J. Med. 274, 731.

276. Ashamalla, G., Walters, N.R. \& Crahan, M. (1966) Recent clinicolaboratory observations in the treatment of acute gonorrhoeal urethritis in man. J. Amer. med. Ass. 195, 1115.

277. Czonka, G.W., Williams, R.E.O. \& CoRSE, J. (1966) T-Strain mycoplasma in nongonococcal urethritis. Lancet, i, 1292.

278. KREIDBERG, M.B. \& CHERNOFF, H.L. (1965) Ineffectiveness of penicillin prophylaxis in cardiac catheterization. J. Pediat. 66, 286.
279. LERNER, P.I. \& WEINSTEIN, L. (1966) Infective endocarditis in the antibiotic era. New Engl. J. Med. 274, 323.

280. Amoury, R.A., Bowman, F.O. \& Malm, J.R. (1966) Endocarditis associated with intracardiac prostheses. J. thorac. cardiovasc. Surg. 51, 36.

281. JAwetZ, E. \& Stone, M. (1966) Penicillinstreptomycin treatment of enterococcal endocarditis. A Re-evaluation. New Engl. J. Med. 274, 710.

282. Benty, H.N., Turck, M. \& Petersdorf, R.G. (1966) Ampicillin in the treatment of enterococcal endocarditis. Ann. intern. Med. 65, 701 .

283. QuinN, E.L., Cox, F. \& DraKe, E.H. (1966) Staphylococcic endocarditis. A disease of increasing importance. J. Amer. med. Ass. 196, 815.

284. SheA, D.W. \& Phillips, J.H. (1966) Mimea endocarditis; a clinical syndrome. Amer. J. med. Sci. 252, 201.

285. MEDEIROS, A.A. et al. (1966) Erythema nodosum and Erythema multiforme as clinical manifestations of histoplasmosis in a community outbreak. New Engl. J. Med. 274, 415.

286. TosH, F.E. et al. (1966) The second of two epidemics of histoplasmosis resulting from the work on the same starling roost. Amer. Rev. resp. Dis. 94, 406.

287. Holland, P. \& Holland, N.H. (1966) Histoplasmosis in early infancy. Amer. J. Dis. Child. 112, 412.

288. Gerber, H.J., Schoonmaker, F.W. \& Vazque M.D. (1966) Chronic meningitis associated with histoplasma endocarditis. New Engl. Med. 275, 74.

289. Tesh, R.B. \& Schneidau, J.D. (1966) Primary cutaneous histoplasmosis. New Engl. J. Med. 275, 597.

290. Goodwin, R.A. et al. (1966) Early chronic pulmonary histoplasmosis. Amer. Rev. resp. Dis. 93, 47.

291. Perry, L., Jenkins, D.E. \& Whitcomb, F.C. (1966) Simultaneously occurring pulmonary coccidioidomycosis and histoplasmosis. Amer. Rev. resp. Dis. 92, 952.

292. Smith, C.D., Furcolow, M.L. \& WeEKS, R.J. (1966) Further ecological studies of the growth of Histoplasma capsulatum in nature. Arch. environm. Health, 12, 755.

293. EmmONS, C.W. et al. (1966) Isolation of Histoplasma captulatum from bats in the United States. Amer. J. Epidem. 84, 103.

294. TeSH, R.B. \& MARQues, R.J. (1966) Histoplasmin sensitivity in Brazil. Amer. J. trop. Med. Hyg. 15, 359.

295. LOURIA, D.B. (1966) Hospital-acquired fungous infections are on the increase. Hosp. Mgmt, 101, 75. HuRwich, B.J. (1966) Monial peritonitis. Arch. intern. Med. 117, 405.

296. DeVita, V.T. et al. (1966) Candida meningitis Arch. intern. Med. 117, 527.

297. Catteral, R.D. (1966) Candida albicans and the contraceptive pill. Lancet, ii, 830.

298. PorTer, P.S. \& LYLE, J.S. (1966) Yeast vulvovaginitis due to oral contraceptives. Arch. Derm. 93, 402.

299. Dvorak, A.M. \& Gavaller, B. (1966) Congenital systemic candidiasis. Report of a case. New Engl. J. Med. 274, 540. 
300. SymmerS, W.S. (1966) Deep-seated fungal infection currently seen in the histopathologic service of a medical school laboratory in Britain. Amer. J. clin. Path. 46, 514.

301. MCFARLAND, R.B. (1966) Sporotrichosis revisited. 65-Year follow-up of the second reported case. Ann. intern. Med. 65, 363.

302. Emanuel, D.A., Wenzel, F.J. \& Lawton, B.R. (1966) Pneumonitis due to cryptostroma corticale (maple-bark disease). New Engl. J. Med. 274, 1413 .

303. ShaW, J.D. \& SChraCK, W.D. (1966) Malaria contracted in Pennsylvania. Publ. Hlth Rep. (Wash.), 81, 413.

304. ChIN, W. \& ConTacos, P.G. (1966) A recently isolated West African strain of Plasmodium ovale. Amer. J. trop. Med. Hyg. 15, 1.

305. Young, M.D., PORTER, J.A. \& JohnSON, C.M. (1966) Plasmodium vivax transmitted from man to monkey. Science, 153, 1006.

306. Diaminodiphenylsulfone for malaria (1966) Amer. med. Ass. News, 9, 1.

307. Haskin, H.H., Stauber, L.A. \& MaCkIN, J.A. (1966) Michinia nelsonii n.sp. (Haplosporidia, Haplosporidiidia): causative agent of the Delaware Bay oyster epidemic. Science, 153, 1414.

308. GSELL, O. (1966) Wandel der Infektions Krankheiten durch die Moderne Therapie und Prophylaxe s e it der Jahrhundertwende. Therapiewoche, 16, 7.

309. Dolan, C.T. \& ChERubin, C.E. (1966) Epidemic haemorrhagic fever in New York City. N.Y. State J. Med. 66, 516.

310. Kartman, L., GoldenberG, M.I. \& Hubbert, W.T. (1966) Recent observations on the epidemology of plague in the United States. Amer. J. publ. Hlth, 56, 1554.

311. Woo, Z.P. \& ReimanN, H.A. (1957) Cutaneous Leishmaniasis-confusion with histoplasmosis. J. Amer. med. Ass. 164, 1902.

312. Hambrick, G.W. \& Evan-PaZ, Z. (1966) Cutaneous Leishmaniasis. Arch. Derm. 93, 396.

313. KURBAN, A.K. et al. (1966) Histopathology of cutaneous Leishmaniasis. Arch. Derm. 93, 396.

314. Medicine's war in Vietnam (1966) Advertisement pages. J. Amer. med. Ass. 196, 29.

315. SchonelL, M.E. et al. (1966) Occupational infections in the Edinburgh abattoir. Brit. med. J. ii, 148.

316. SCHNURRENBURGer, P.R. \& MASTERSON, R.A. (1966) The prevalence of antibodies against selected zoonotic diseases in abattoir workers. Arch. environm. Health, 13, 336.

317. ReED, C.F. \& SCHNURRENBERGER, P.R. (1966) On fever surveilance in Ohio. Amer. J. Epidem. 84, 234.
318. Johnson, J.E. \& KADULL, P.J. (1966) Laboratoryacquired $\mathrm{Q}$ fever. A report of fifty cases. Amer. J. Med. 41, 391.

319. BARRETT, P.K.M. \& GREenberG, J.M. (1966) Outbreak of ornithosis. Brit. med. J. ii, 206.

320. Shopp, H.D., Stille, W. \& KRUger-HansenSCHOOP, U. (1966) Diagnosis and epidemiology of ornithosis. Munchen. med. Wschr. 108, 826.

321. Feathered friends leave owners short of breath (1966) Med. Wld News, 7, 154.

322. SCHACHTER, J. et al. (1966) Isolation of Bedsonia from the joints of patients with Reiter's syndrome. Proc. Soc. exp. Biol. (N.Y.), 133, 283.

323. DeCKer, J.L. \& WARD, J.R. (1966) The relationship of mycoplasma (PPLO) to rheumatoid arthritis and related diseases: a working conference. Bull. rheum. Dis. 16, 412.

324. Theologides, A. \& KenNEDY, B.J. (1966) Clinical manifestations of toxoplasmosis in the adult. Arch. intern. Med. 117, 536.

325. Warren, K.S. \& Dingle, J.H. (1966) A study of illness in a group of Cleveland families. XXII. Antibodies to toxoplasma gondii in 40 families observed for ten years. New Engl. J. Med. 274, 993.

326. De Roever-Bonnet, H. \& Hillenbrink, H.C. (1966) Med. T. Geneesk. 110, 378.

327. SADUN, E.H. et al. (1966) Schistosoma mansoni in the chimpanzee; parasitologic, clinical, serologic, pathologic and radiologic observations. Amer. J. trop. Med. Hyg. 15, 496.

328. JORDAN, P. (1966) Trial of amhilhar, a nitrothiazole derivative, in $S$. mansoni infection in Tanzania. Brit. med. J. i, 276.

329. Diesch, D.L. \& McColloch, W.F. (1966) Isolation of pathogenic leptospires from waters used for recreation. Publ. Hlth Rep. 81, 299.

330. ReimanN, H.A., Havens, W.P. \& Bucher, C.J. (1940) Leptospirosis: A public health hazard. Report of a small outbreak in bathers. $J$. Amer. med. Ass. 116, 289.

331. Beskin, C.A., Colvin, S.H. \& Beaver, P.C. (1966) Pulmonary dirofilariasis. Cause of pulmonary nodular disease. J. Amer. med. Ass. 198, 665 .

332. DanaraJ, T.J. et al. (1966) The etiology and pathology of eosinophilic lung (tropical eosinophilia). Amer. J. trop. Med. Hyg. 15, 183.

333. Barghoorn, E.S. \& Schoff, J.W. (1966) Microorganisms three billion years old from the Precambrian of South Africa. Science, 152, 758. 